\title{
Paternalist liderliğin iş performansı ve alt boyutlarına etkisi: $X$, Y ve $Z$ kuşakları üzerine bir araştırma
}

\section{The effect of paternalistic leadership on job performance and job performance subdimensions: $A$ research on $\mathrm{X}, \mathrm{Y}$ and $\mathrm{Z}$ generations}

Gönderim Tarihi / Received: 23.05.2021

Kabul Tarihi / Accepted: 24.11.2021

Yahya KATI"1

Doi: https://doi.org/10.31795/baunsobed.941355

ÖZ: Örgütlerdeki yönetim tarzları ve liderlerin davranışları, işgörenlerin performansını yakından etkilemektedir. Bu etkiler son yıllarda önemli ve kapsamlı araştırma konularından biri olmuştur. Kuşaklar son dönemlerde, sosyal medyada, günlük hayatta ve iş hayatında üzerinde önemle durulan ve farklılıklarını anlamak için çaba gösterilen bir konu olmuştur. Bu kapsamda, iş hayatında farklı özellik, tutum ve düşünce kalıplarına sahip ve aynı koşullarda çalışan farklı kuşaklara yönelik çalışmalar görece önem kazanmıştır. Bu çalışmanın amacı, emik yaklaşım çerçevesinde daha çok Doğu kültürlerinde kabul gören ve çalışanlarına bir baba figürü gibi davranan paternalist liderliğin, çalışanların iş performansı ve alt boyutlarına etkisi ve bu etkinin kuşaklara göre değişip değişmediğini araştırmaktır. $\mathrm{Bu}$ amaçla; Antalya, Balıkesir ve Çanakkale'de turizm sektöründe çalışan, $X, Y$ ve $Z$ kuşaklarına ait 306 kişiye anket uygulanmıştır. Çalışmanın sonuçlarına göre, paternalist liderlik ile iş performansı $(\beta=$ $0.48, p<0.01)$, bağlamsal performans $(\beta=0.51, p<0.01)$ ve görev performansı $(\beta=0.37, p<0.01)$ arasında istatistiksel olarak anlamlı ve pozitif ilişkiler tespit edilmiştir. Ayrıca, paternalist liderlik ile iş performansı ilişkisinde, $\mathrm{X}$ ve $\mathrm{Y}$ kuşaklarının $(\beta=-0.26, p<0.01)$ düzenleyici etkisi tespit edilmiştir. Başka bir ifadeyle, paternalist liderliğin iş performansı üzerindeki etkisi, $\mathrm{X}$ ve $\mathrm{Y}$ kuşaklarına göre anlamlı düzeyde farklılaşmaktadır.

Anahtar Kelimeler: Paternalist liderlik, İş performans1, Görev performans1, Bağlamsal performans, Kuşaklar

ABSTRACT: Management styles and behaviors of leaders closely affect the job performance of employees in organizations. These effects have been one of the most important and comprehensive research topics in recent years. Recently, generations has been an important issue at social media, daily life, and business life, and an effort has been made to understand generation differences. In this context, studies on generations which have different characteristics, attitudes, and thought patterns in business life and work under the same conditions have gained relative importance. The aims of this study within the framework of the emic approach are to determine the effects of paternalistic leadership, which is accepted in Eastern cultures and treats its employees as a father figure, on the job performance and job performance subdimensions of employees and to investigate whether this effect differs according to generations. To this end, a questionnaire was administered to 306 people belonging to the $\mathrm{X}, \mathrm{Y}$ and $\mathrm{Z}$ generations working in the tourism sector in Antalya, Balıkesir, and Çanakkale. According to the results of the study, statistically significant and positive relationships were found between paternalistic leadership and job performance $(\beta=0.48, p<0.01)$, contextual performance $(\beta=0.51, p<0.01)$, and task performance $(\beta=0.37, p<0.01)$. Additionally, in the relationship between paternalistic leadership and job performance, the $\mathrm{X}$ and $\mathrm{Y}$ generations $(\beta=-0.26, p<0.01)$ have a moderator effect. In other words, the effect of paternalistic leadership on job performance differs significantly according to the $\mathrm{X}$ and $\mathrm{Y}$ generations.

Keywords: Paternalistic leadership, Job performance, Task performance, Contextual performance, Generations.

\footnotetext{
* Sorumlu Yazar / Corresponding Author

${ }^{1}$ Dr., Balıkesir Üniversitesi/İktisadi ve İdari Bilimler Fakültesi/İşletme/Yönetim ve Organizasyon, yahyakati@balikesir.edu.tr, https://orcid.org/0000-0002-3917-509X

2 Dr Öğr. Üyesi, Bandırma Onyedi Eylül Üniversitesi/Turizm ve Otel İşletmeciliği/Sağlik Turizmi İşletmeciliği, atoptas@ bandirma.edu.tr, https://orcid.org/0000-0003-3517-7351
} 


\section{EXTENDED ABSTRACT}

\section{Literature review}

In this study, paternalistic leadership, job performance (task performance and contextual performance) and generations differences (X, Y and Z) are discussed. In paternalistic cultures, managers undertake the parent's role. Paternalistic leaders try to preserve their subordinates and ensure their wellbeing. In return, they are in the expectation of loyalty, respect and obedience from the subordinates. Paternalistic leadership is perceived negatively by western societies due to a patriarchy relationship between the leader and its subordinates (Pellegrini \& Scandura, 2006: 267). Paternalistic leadership is one of the most frequently studied and addressed issues in Eastern societies (such as Turkey) within the framework of emic approach. Job performance is the concept related to the role responsibilities expected from the employees, the skills they should have, and how much they fulfill the expected behaviors (Armstrong, 2006: 496). In the literature, job performance is considered as task performance and contextual performance. Task performance is related to what is expected of employees due to their role. Contextual performance refers to roles undertaken outside of the defined work (Armstrong, 2006: 715; Jawahar \& Carr, 2007: 332). The concepts of generation and generation differences are topics studied for many years in areas such as anthropology, sociology, and social psychology (Hung et al., 2007: 838). Generation can be described as human community, due to similar experiences (economic, social, political etc) they have similar characteristics, thoughts, attitudes (Kupperschmidt, 2000: 66).

Within the framework of this descriptions, the purposes of this research are to determine the relationship between paternalistic leader behaviors and job performance and to determine whether this relationship differs in terms of $\mathrm{X}, \mathrm{Y}$ and $\mathrm{Z}$ generations.

\section{Methodology}

The research is designed in descriptive genre. The population of the study consists of 720 people working in 20 tourism enterprises operating in Antalya, Balıkesir and Çanakkale. The questionnaire was applied by sharing links on the web between April 15 and April 30, 2021. The convenience sampling method was used while applying the questionnaires. The study was conducted on a voluntary basis and 311 questionnaires were filled out. It was determined that five of the 311 questionnaires obtained were filled inappropriately and they were removed from the data set. In this case, the final number of questionnaires included in the analysis was 306.

In the study, ten-item scale was used to measure paternalistic leadership consisted by Aycan et al. (2006). The Cronbach alpha value of the scale was measured as 0.91. In the study, twenty-five-item adapted from Goodman \& Svyantek (1999: 261)'s job performance (task performance and contextual performance) scale was used to measure job performance. The variables in the questionnaire were measured with Likert type scales such as $1=$ Strongly disagree-5=Strongly Agree. The Cronbach alpha value of the task performance scale was measured as 0.79 . The Cronbach alpha value of the contextual performance scale was measured as 0.82 . Overall job performance scale's Cronbach alpha value was measured as 0.88 . Generation cohorts are determined by the age ranges. The age ranges are based on the 1965-1979 (Generation X), 1980-1999 (Generation Y) and 2000 and later (Generation Z) classifications, which are frequently encountered in the literature (Crampton \& Hodge, 2009: 1; Becton et al., 2014: 3). "Kurtosis" and "skewness" values have been examined in order to determine whether the data were normally distributed or not (Hair et al., 2010: 70; Eroğlu, 2010: 212). Kurtosis and skewness values of the variables of paternalistic leadership (kurtosis 0.26 , skewness -0.60 ) and job performance (kurtosis 1.79, skewness -0.77) were found to be within normal ranges (Çokluk et al., 2016: 16). In the study, confirmatory factor analysis was used to test previously determined and tested factors (Pallant, 2007: 179). In the job performance scale, one item in task performance factor and four items in contextual performance factor were omitted due to factor loads lower than 0.50 (Hair et al., 2010: 678).

In the study, correlation analysis was conducted to determine the relationship between paternalistic leadership and job performance. Regression analysis was conducted to determine the impact of paternalistic leadership on job performance. Finally, the moderating effect analysis was conducted to 
determine the effect of generational differences on the relationship between paternalistic leadership and job performance. With these analyses, the following hypotheses have been tested.

Hypothesis 1: Paternalistic leadership has a statistically significant and positive effect on job performance.

Hypothesis 1a: Paternalistic leadership has a statistically significant and positive effect on contextual performance.

Hypothesis 1b: Paternalistic leadership has a statistically significant and positive effect on task performance.

Hypothesis 2: Generations have a moderating effect in the relation of paternalistic leadership and job performance.

Hypothesis 2a: $\mathrm{X}$ and $\mathrm{Y}$ generations have a moderating effect in the relation of paternalistic leadership and job performance.

Hypothesis 2b: $\mathrm{X}$ and $\mathrm{Z}$ generations have a moderating effect in the relation of paternalistic leadership and job performance.

Hypothesis 2c: $\mathrm{Y}$ and $\mathrm{Z}$ generations have a moderating effect in the relation of paternalistic leadership and job performance.

\section{Findings and discussion}

Regression analysis was conducted to determine the effect of paternalistic leadership on job performance. A significant and positive effect of paternalist leadership on job performance $(\beta=0.48, p$ $<0.01)$, contextual performance $(\beta=0.51, p<0.01)$ and task performance $(\beta=0.37, p<0.01)$ were determined. In addition, the moderating effect of generations on the relationship of paternalist leadership and job performance were examined. According to the moderating effect analysis results, the moderating effect of the $\mathrm{X}$ and $\mathrm{Y}$ generations $(\beta=-0.26, p<0.01)$ in the relationship between paternalistic leadership and job performance has been identified. In other words, the effect of paternalistic leadership on job performance differs significantly according to generations $\mathrm{X}$ and $\mathrm{Y}$. On the other hand, the moderating effect of the $\mathrm{X}$ and $\mathrm{Z}$ generations $(\beta=-0.07, p>0.05)$ and the $\mathrm{Y}$ and $\mathrm{Z}$ generations $(\beta=$ $0.12, p>0.05)$ in the relationship between paternalistic leadership and job performance has not been determined. According to the results of this analysis, hypothesis 1 , hypothesis $1 \mathrm{a}$, hypothesis $1 \mathrm{~b}$, hypothesis $2 \mathrm{a}$ were accepted. Hypothesis $2 \mathrm{~b}$ and hypothesis $2 \mathrm{c}$ were rejected. Hypothesis 2 was partially accepted.

\section{Results and recommendations}

According to this research, it was concluded that paternalistic leadership has a significant and positive effect on job performance. In addition, the moderating effect of the $\mathrm{X}$ and $\mathrm{Y}$ generations in the relationship between paternalistic leadership and job performance has been determined. In other words, the effect of paternalistic leadership on job performance differs significantly according to generations $\mathrm{X}$ and Y. This result shows that paternalistic leadership is not as effective as on generation Y's job performance unlike in the case of generation X's job performance. Accordingly, business managers should approach generation $\mathrm{Y}$ with a more flexible and participatory management style, unlike the $\mathrm{X}$ generation. This will be important as the generation Y participate to business life. On the other hand, the moderating effect of the $\mathrm{X}$ and $\mathrm{Z}$ generations and the $\mathrm{Y}$ and $\mathrm{Z}$ generations in the relationship between paternalistic leadership and job performance have not been determined. The main reason for this result may be the small number of people generation $\mathrm{Z}$ in the sample due to the new entry of Generation $\mathrm{Z}$ into business life. For this reason, keeping the sample larger in future studies and doing the study in different sectors may provide clearer results.

As the number of generations working together in enterprises increases, studies on understanding the characteristics of generations and managing these characteristics have started to appear more frequently in the literature. However, research the personalities of the employees as well as the characteristics of the generations will provide clearer results. It would be beneficial to research the generations with Hofstede's National Cultural Dimensions (Power distance, masculinity and femininity, uncertainty avoidance etc) within the framework of the emic approach. 


\section{Giriş}

Paternalist liderlik, geçmişten günümüze kadar gelen ataerkil davranışların sergilendiği, daha çok kolektivist kültür anlayışının hakim olduğu toplumlarda görülen bir anlayışı kapsamaktadır. Paternalist lider davranışları bazı toplumlarda ve kuşaklarda kabul görürken, bazı toplumlar tarafından kabul görmemekte hatta bu davranışlar tuhaf karşılanmaktadır. İşgörenlerin, lider ile aralarındaki ilişkinin niteliği ve liderin davranışlarının, iş performansını etkilendiği bilinmektedir. İşgörenlerin, örgütün amaçlarını ve hedeflerini gerçekleşmesinde göstermiş oldukları çaba olarak ifade edilen iş performası; alanyazında görev performansı ve bağlamsal performans şeklinde iki başlık olarak ele alınmaktadır. Görev performansı, işgörenlere tanımlanan işin niteliği ve analizini kapsayan görev tanımlarında sergilemiş oldukları çabayı göstermektedir. Bağlamsal performans, işgörenlerin kendi yükümlülükleri dışında çalıştıkları örgütün amaçlarına ve hedeflerine ulaşmada göstermiş oldukları kurumsal bütünlüğe katkıları olarak ifade edilebilir. Son yıllarda, çalışma hayatında farklı düşünceler ve iş anlayışlarına hakim olan kuşakların iş hayatında birlikte çalıştıkları görülmektedir. Örgütler açısından bütünlüğün ve örgüt çalışanlarının sürece katılımının önemli olduğu günümüz koşullarında, kuşaklar arasındaki farklılıkların iş performansına yansıması, bu araştırmanın problemini oluşturmaktadır. Türkiye'nin de içinde bulunduğu Doğu kültürlerinde, paternalist lider davranışlarının daha çok kabul gördüğüyle ilgili araştırmaların sayısı oldukça fazladır. Yapılan bu araştırma, kuşaklar arasındaki farklılıklardan dolayı Türkiye'de paternalist lider davranışlarının iş hayatında yoğun olarak kendini göstermeye başlayan Y kuşağında kabul görmediğini göstermektedir. Bu çalışma, daha önce ortaya koyulan paternalist lider davranışlarının farklı kuşaklar açısından farklılaşabileceğini sorgulaması sebebiyle özgün bir nitelik taşımaktadır. Araştırmada, verilerin elde edilmesi amacıyla oluşturulan ölçek internet üzerinden link aracılığıyla katılımcılara iletilmiştir. Yaklaşık 450 kişiye iletilen anketi 311 kişi doldurmuştur. Ancak, bazı katılımcılar anket formunu eksik ve özensiz bir şekilde doldurması nedeniyle çalışmanın analizlerinde 306 anket kullanılmıştır. Örnekleme bakıldığında; X kuşağı 73 kişi, Y kuşağ 145 kişi ve $\mathrm{Z}$ kuşağı 88 katılımcıdan oluşmaktadır. $\mathrm{Bu}$ durum, araştırmanın sınırlılığını ve kısıtlılığını oluşturmaktadır. Çalışma, sınırlı il ve çalışan sayısı ile yapılmıştır. Örneklemin genişletilmesi ve çalışmanın farklı sektörlerde de yapılarak desteklenmesi gerekmektedir.

\section{Literatür taraması \\ Paternalist liderlik}

Paternalist liderlik tarzına geçmeden önce paternalizm kavramına değinmekte fayda vardır. Paternalizm, Latince "pater (baba)" kelimesinden türemiştir ve diğerlerine koruyucu (baba, ebeveyn gibi) bir şekilde davranma, anlamına gelmektedir (Suber, 1999: 632). Paternalizm kavramı, köken itibariyle kişilerin, kurumların veya devletlerin bir baba figürü (rolü) gibi üyelerini koruması, kollaması ve çıkarlarını gözetmesi olarak ifade edilebilir (Feinberg, 1971: 105). Alanyazında, paternalizm ve paternalist liderlik kavramları Max Weber (1864-1920)'in çalışmaları ile temellendirilmiştir. Weber paternalizm kavramına, yasal hakimiyetin bir türü olarak değinmiştir (Pellegrini ve Scandura, 2008: 568, Köksal, 2011: 104). Sonraki çalışmalarda Silin (1976), Tayvan'daki liderlik davranışlarının Batı kültüründeki liderlik davranışlarından otorite, astlarla olan ilişkiler, kontrol mekanizmaları gibi konularda farklılıklara odaklanmıştır (Cheng vd., 2004: 91). Redding (1990) Hong Kong, Singapur, Tayvan ve Endonezya'daki yetmiş iki yönetici ile görüşmeler yaparak işletmelerdeki yönetim uygulamalarını incelemiş̧ir. Bu görüşmeler sonucunda, paternalizmin kilit unsur olduğu farklı bir ekonomik kültür (Çin kapitalizmi) belirlemiştir (Farh ve Cheng, 2000: 88). Westwood ve Chan (1992) ve Westwood (1997), "Westwood paternalist liderlik modeli" olarak adlandırdıkları modelde paternalist liderliği, didaktik liderlik, saygınlık oluşturma, politik manipülasyon, biçimsel olmayan iletişim, patronluk ve sosyal mesafe gibi bileşenlerle birlikte ele almıştır (Westwood, 1997: 464).

Paternalist liderlik, birlikte çalıştığı kişileri bir baba figürü gibi koruyan, bunun karşıllğında ise onlardan sayg1, bağl1lık ve sadakat bekleyen liderlik türüdür (Aycan, 2006: 455). Başka bir deyişle paternalist liderlik, disiplin ve otoriteyi babacan bir tavırla sağlayan, astlarıyla kişisel ilişkiler kuran ve astlarını koruyan, astlarına rehberlik eden ve bunların karşılığında astlarından bağlılık ve sadakat bekleyen liderlik türü olarak ifade edilebilir (Hayek vd., 2010: 371). Bu bilgiler 1şığında paternalist liderlik, çalışanlarına aile büyüğüymüş gibi davranan, çalışma hayatlarının yanında günlük hayatları ile de ilgilenen, çalışan kişiler hakkında onların iyiliği için kararlar aldığını düşünen, çalışanlardan bağlılık ve sadakat bekleyen liderlik tipi olarak ifade edilebilir. Doğu kültürlerinde paternalist anlayışın olumlu 
karş1landığı söylenebilir. Buna karşılık, Batı kültürlerinde eşitçi ve bireysel bir anlayış hakim olduğundan, gücü ve yetkiyi elinde bulunduran kişiler veya kurumların bu yetkiyi gereğinden fazla kullanması olumsuz bir durum olarak görülür (Tolay, 2020: 126). Alanyazın incelendiğinde, paternalist liderliğin boyutları birç̧ok çalışmacı tarafından ve farklı şekillerde sınıflandırıldığı görülmektedir. Farh ve Cheng (2000: 98)'e göre paternalist liderliğin "otoriter", "yardımsever" ve "ahlaki" boyutlan vardır. Otoriter boyutu, hiyerarşik yapı içinde liderin sözünün geçtiği, yukarıdan aşağıya iletişimin kullanıldığ 1 , dar denetim alanının olduğu ve sıkı kontrolün yapıldığı, liderin astları üzerinde hakimiyetinin olduğunu, ifade etmek için kullanılan boyuttur. Yardımseverlik boyutu, paternalist liderin astlarına karşı aynı ailenin üyesi gibi davranması, astlarına bireysel ilgi göstermesi ve sevecen yaklaşması, astlarının çıkarlarını koruması ve iş dışında da sosyal ilişkilerinin devam etmesi vb. ile ilgili boyuttur. Ahlaki boyut ise paternalist liderlerin kişisel çıkarları için otoriteyi kötüye kullanmaması, kişisel çıkarlarla iş çıkarlarını birbirine karıştırmaması, iş ve kişisel ilişkilerini örnek olacak şekilde yönetmesi vb. özellikler ile açıklanan boyuttur. Kim (1994)'e göre paternalist liderliğin "çıkarcl” ve "iyi niyetli", iki boyutu vardır. Bu iki boyut arasındaki fark liderin astlarına yönelik davranışlarını güdüleyen güçtür. Paternalizmin "Çı karcl” boyutunda yapılan iş ön plandayken, "iyi niyetli" boyutunda ise astların iyiliğini sağlamak ön plandadır. Bu nedenle "çıkarcı" boyutta astlara gösterilen cömertlik ve özenin arkasındaki güdüleyici etken işin tamamlanmasıyla ilgili endişe, "iyi niyetli" boyutta ise astların iyiliğine yönelik endişedir (Aycan, 2001: 6).

\section{İs performansı}

Performans; işgörenlerden beklenenlerin ne derece iyi gerçekleştirildiği ile ilgili kavramdır (Selamat ve Heryanto, 2019: 142). Performans kavramını örgüt performans1, iş performansı, işgören performansı ve bireysel performans olarak birçok boyutta ele almak mümkündür. Alanyazında iş performansı; kişilerin çalıştıkları işletmelerin belirlemiş olduğu hedeflere ve amaçlara ulaşmalarına katkı sağlayacak faaliyetlerin ve davranışların bütünü, olarak açıklanmaktadır. Bu bağlamda işgören performansı, iş ile ilgili amaçlara ve/veya standartlara ne ölçüde ulaşıldığını gösterir (Uysal, 2015: 33; Özer, 2019: 1014). Yapılan çalışmalarda, performans yönetimi süreci üç kategoride ele alınmıştır. Bunlar; Denisi ve Murphy (2017) tarafından birinci kategoride yer alan performans yönetiminin açılanması ve geliştirilmesine yönelik çabaların ele alındığı ve yapılan ilk çalışma olduğu, ikinci kategoride yer alan bireysel performansın iyileştirilmesine yönelik süreçlere yönelik bakış açıları ve üçüncü kategoriyi oluşturan işletmelerin düzeylerine göre performansın iyileştirilmesine yönelik çalışmalardır (Denisi ve Murphy, 2017: 427). Günümüzde, iş performansı kavramının işletmelerin yönetimlerinin iş tanımlarında yer alan standartlar göz önüne alınarak bireysel ve örgütsel başarı düzeylerine ulaşmada bir ölçüt olarak kullanıldığı görülmektedir. İş performansı; üretilen mal ve hizmetlerin miktarı biçiminde ifade edilmiş olsa da, işlevsel olarak kişilerin yetenekleri ve motivasyonları arasındaki ilişkinin etkinlik, verimlilik ve çıktı kavramlarının neticesi şeklinde ifade edilmektedir (Çöp ve Doğanay, 2020: 37). İş performansın yönetilmesi; kişilerin ve ekiplerin performansını tanımlama, ölçme ve geliştirme ile işletmenin kuruluş amaçları ve geleceğe yönelik hedefleri ile uyumlu hale getirme sürecidir (Aguinis vd., 2012: 385).

İş hayatında, bir işletmenin başarısında ekip çalışmasının rolü çok önemlidir. Ekip çalışması genellikle belirli bir düzeyde yetkinlikleri, becerileri ve görevleri birlikte yerine getirmeye çabalayan çalışan grupları arasındaki iş birliği olarak tanımlanır. Ekip performansı, büyük ölçüde ekip etkileşimine bağlıdır. Çalışanların sinerji içinde iyi bir performans yakalaması olasılığı daha yüksektir. Diğer taraftan ekip çalışmaları, kendi aralarındaki etkileşim nedeniyle çalışanların yenilikçi ve yaratıcı fikirleri keşfetmelerini sağlayacaktır (Jawabreh vd., 2020: 651). İşletmelerin küresel boyutta rekabet edebilmeleri için özgün fikirlere sahip olabilmeleri çok önemlidir. Çalışanlar, rekabet avantajının en güçlü kaynaklarından biridir. Ekip çalışmaları farklı özelliklere sahip çalışanların bütün yetkinlikleri, yetenekleri ve becerilerini bir araya getirdiği için işletmenin üretkenliğini artıracağı söylenebilir. Ayrıca üstlenilen görev ve yükümlülüklerin sorunsuz bir şekilde yerine getirilmesini sağlar ve ortaya çıkan problemler daha hızlı bir şekilde çözüme ulaşır (Kibichii vd., 2016: 52).

Performans yönetimi, örgüt sisteminin ve çalışanların etkin çalışmasını sağlayan birçok amaca hizmet eder. Bunlardan birincisi stratejik amaçlardır. Çalışan faaliyetleri işletme misyonu ve hedefleri ile ilişkilendirilerek geleceğin koşullarına göre yönlendirilir. İşletmenin amaçları, beklenen etkinlik ve 
verimlilik düzeyleri belirlenir. Çalışanların bunları benimsemesi, kişisel yeteneklerinin ortaya çıkarılması ve başarı elde etmek için önemli bir özellik olan inisiyatif kullanma ve risk alma eğiliminin geliştirilmesi sağlanır. Bu sayede çalışanların, görevlerin ve sorumlulukların daha net anlaşılması, işletme amaçlarının kavranması, iş performansı, işletmeye sağlanan katkılar vb. konularda bilinç kazanılır. İkincisi, yönetsel amaçlardır. Ücretlendirme, terfi, ödüllendirme, transfer, disiplin cezaları, iş feshi, sendikal işler, güvenlik ve sağlık gibi konularda adil ve doğru karar verilmesi iş süreçlerine dair bilgilere bağlıdır. Bu bilgiler olmadan yönetsel karar mekanizmasının işlemesi güç bir durum haline gelir (Özer, 2013: 40). Performans yönetiminin bir diğer amacı, görev tanımlarında ve iş gereklerinde yer alan standartlara hangi düzeyde ulaşıldığına dair geri bildirim almaktır. Performans geri bildirimi insan kaynakları planlamasının etkin olmasına, işgörenlerin güçlü ve zayıf yönlerinin farkına varmalarına, eğitim ihtiyaçlarının belirlenmesine, çalışanların görev ve sorumluluklarıyla ilgili doğru kararlar almalarına yardımcı olur. Gerektiğinde örgütde değişime gidilerek yeni bir yönetim felsefesi benimsenir ve uygulanır. Bu sayede, faaliyetlerde ortaya çıabilecek hata ve gecikmelerin, yeterli niteliği olmayan işgörenlerin, niteliksiz mal ve hizmet üretiminin önüne geçilebilir (Aguinis, 2013: 26).

Performans yönetimi, işgören performansını iyileştirmek için tasarlanmış, çok çeşitli faaliyetler, politikalar ve prosedürleri kapsamaktadır. Bu uygulamalar performans değerlendirme ile başlar, geri bildirim, hedef belirleme ve eğitimin yanı sıra ödül sistemlerini de içerir. Bu nedenle işgörenlerin performansının değerlendirilmesi ile başlayan süreç daha sonra nihai amaç olan işletme performansının iyileştirilmesi amacıyla tutarlı bir bireysel performans iyileştirmeye odaklanır. İşletmeden işletmeye değişen bu süreç; bir işletmenin işgörenlerinin fiziksel ve bilişsel yeteneklerini en iyi şekilde yönlendiren çalışma ortamının oluşturulmasını amaçlamaktadır. Performans yönetimi anlayışı, yöneticilerin ve işgörenlerin performansı birlikte geliştirmesi temeline dayanır (Kibichii vd., 2016: 52; Denisi ve Murphy, 2017: 421).

Alanyazında iş performansına, görev performansı ve bağlamsal performans olarak iki başlıkta değinilmektedir. Borman ve Motowidlo (1997) yapmış oldukları çalışmalarda bağlamsal performans kavramını kullanmışlar ve örgüt içinde işgörenlerin görev ve bağlamsal olmak üzere iki davranış şekli sergilediklerini belirtmişlerdir.

\section{Görev performanst}

Görev performansı; işgörenlerin bir örgütte çalışıyor olmalarına bağlı olarak kendilerinden beklenen rol davranışlarına yönelik çabaları ile ilgilir. Görev performansı, üretilen mal ve hizmetlerin örgütün sahip olduğu temel teknik süreçleri ve bu süreçlere destek sağlayan davranış kalıplarını kapsamaktadır (Özaydın ve Çelik, 2020: 183). Görev performansı, işgörenlerin iş tanımları kapsamında yapmakla yükümlü oldukları görevlerle ilgili etkinlik ve verimliliğin düzeyleridir. Görev performanıs1, iş performansının bireysel kısmını yansıtan boyuttur (Kaya ve Dinç Elmalı, 2021: 123). Görev performansının "teknik" ve "liderlik" olarak iki boyutu bulunmaktadır. Teknik görev performansında teknik yeteneklerle birlikte, örgütleme, planlama ve iş kararları etkinken, liderlik görev performansında, amaçlar kapsamında yönlendirme, güdüleme, rehberlik etme, ve geri bildirim sağlama bulunmaktadır (Ünlü ve Yürür, 2011: 184; Özaydın ve Çelik, 2020: 183).

\section{Bă̆lamsal performans}

Bağlamsal performans (içerik performansı) ise çalışanların iş tanımlarında yer alan yükümlülüklerinden daha fazlasını içermektedir. Bağlamsal performans; tanımlanmış işin dışında üstlenilmiş olan rolleri ifade etmekte kullanılır. İş arkadaşlarına yardımcı olma ve onları desteklemekle birlikte, işle ilgili verilen görevlerde gönüllü olma gibi davranışları da kapsamaktadır. Kurumsal bütünlüğe katkı sağlayan ve çalışma ortamını sosyal ve psikolojik açıdan koruyan tüm eylemlerdir (Jawahar ve Carr, 2007: 332; Ünlü ve Yürür, 2011: 185; Çankır ve Çelik, 2018: 56). İş arkadaşlarına yardım etme, kişisel hoşnutluk, kurallara uyma gibi örgütsel amaçların gerçekleşmesinde fazladan gösterilmesi gereken davranışları içerir (Kaya ve Dinç Elmalı, 2021: 123). Bağlamsal performansa çalışma ortamını psikolojik ve sosyal anlamda geliştirme, İş arkadaşlarına yardım etme, kendi işini başarıyla tamamlamada ve kendisinden beklenen roller dışındaki rollerde de istekli olma, örgütün kural ve prosedürlerini takip etme, operasyon sürecinin işlemesini sağlama vb. örnek olarak verilebilir. 
İşletmeler ve işgörenler için çok önemli olan performans yönetimi, insan kaynakları yönetimi açısından hayati bir öneme sahiptir. Bu nedenle işgörenlerin bireysel performanslarının ve bununla birlikte işletme performansının iyi olabilmesi için performans yönetim sürecinin sağlıklı bir şekilde yürütülmesi gerekmektedir. İşgörenlerin sürekli değişen şartlara uyum sağlayabilmesi; işin gerekliliğine göre duygusal ve bilişsel boyutlarla birlikte zorunludur ve bu durum uyum performansı olarak tanımlanır (Kaya ve Dinç Elmal1, 2021: 123). Örgütlerde performans yönetimi, amaçlara ulaşmanın önemli bir kriteridir. Performans yönetiminde, işgörenlerin performans değerlendirilmesinin adil ve şeffaf olması, büyük önem teşkil etmektedir. Bu tespitler işgörenlerin kendi zayıf ve güçlü yönlerini görmelerine ve mesleki gelişimlerine katkı sağlayacaktır. Bu bağlamda örgütlerde performans değerlendirme; insan kaynağının seçiminin çeşitlendirilmesine, kişilerin başarı ve başarısızlıklarının tespitine, güçlü yanlarının öne çıkartılmasına ve işgörenlerin kariyer planlamalarının yapılmasına yardımcı olmaktadır (Çöp ve Doğanay, 2020: 37).

\section{Kuşaklar ve özellikleri}

Çalışmanın bu bölümünde öncelikle kuşak kavramına değinilmiş, ardından $\mathrm{X}, \mathrm{Y}$ ve $\mathrm{Z}$ kuşakları özellikleri çerçevesinde ele alınmıştır.

\section{Kuşak kavramı}

Türk Dil Kurumu sözlüğünde kuşak "yaklaşık olarak aynı tarihlerde doğmuş, aynı çağın şartlarını dolayısıyla birbirine benzer sorunları, sıkıntıları ve kederleri paylaşmış, benzer ödevlerle yükümlü olmuş kişiler topluluğu", şeklinde açıklanmıştır (tdk.gov.tr, 02.04.2021). Konuyla ilgili yapılan çalışmalarda hangi kuşağın hangi yaş aralığında doğduğu hakkında tam bir fikir birliği bulunmamaktadır. Ancak kuşaklar, belirli bir zaman diliminde doğmuş olmanın getirdiği yaşam biçimlerinden tutum ve davranışlarına kadar benzerlik gösteren, sosyal şartların gerekleri doğrultusunda aynı tarihsel olayları deneyimlemiş belirli kesimler olarak ifade edilmektedir (Toruntay, 2011: 64; Ayhün, 2013: 96). Yapılan çalışmalara göre kuşakların yaşamını sürdürdükleri dönemlere göre kendi kültürel değerleri, her kuşağın kendine özgü olumlu ve olumsuz özellikleri, kendilerine özgü düşünce tarzları ve değer yargıları bulunmaktadır. Genel anlamda eski kuşaklar ile yeni kuşaklar arasında algılar, tutumlar ve davranışlar açısından farklılık görülmektedir. Bu durum günlük hayatta ve iş hayatında kuşaklararasında anlaşmazlıklara neden olabilmektedir (Çakmak, 2013: 5). Her kuşağın kendine özgü özelliklerinin olması, iş ve özel yaşamlarında farklı düşünceler, algılar, tutumlar ve davranışlar olarak kendini göstermektedir (Bayarçelik ve Hıdır, 2020: 3).

\section{$X$ kuşağı dönemi ve X kuşağının özellikleri}

1965-1979 tarihlerinde doğan kişiler X kuşağı olarak ifade edilmektedir. Otoriteye saygıl1, verilen görevleri eksiksiz yerine getiren, diğer kuşaklara göre daha koruyucu, denge ve düzeni önemseyen, kanaat etmeyi bilen, idealleri olan, işine ve iş yerine bağl, eğitime önem veren, dengeli ve aktif bir hayat görüşü olan, gönüllü, istekli, ailesine düşkün bir kuşaktır (Deca, 2016: 3). Doğdukları tarih aralıklarında gerçekleşen ekonomik, sosyal ve siyasi olaylardan doğrudan etkilenmişlerdir. Bu kuşak, eskiyle yeniyi birlikte yaşayan ve otorite baskısıyla karşılaşmış kayıp kuşak olarak da bilinmektedir (Şalap, 2016: 33). $\mathrm{Bu}$ duruma X kuşağının, hem siyah beyaz yayın yapılan tek kanallı siyah beyaz televizyonları hem de son sistem uydulardan birçok yayın yapan televizyonları görmeleri örnek verilebilir. X kuşağı otoriteye saygılı olan, işlerine ve kendilerine verilen görevlere bağl1, görevlerine kendilerini adayan, verilen işleri en iyi şekilde ve zamanında yapmaya çabalayan bir kuşaktır. X kuşağı yaptığg işten zevk alan, otoriteyle iletişimine dikkat eden ve işini önemseyen bir kuşaktır. X kuşağının en önemli özelliklerinden biri de ailesine olan düşkünlüğü ve sadakat duygusunun yapmış oldukları işe ve iş yerine yansımasıdır. Yaptıkları işe ve iş yerine sadık olmalarının yanı sıra aldıkları ücret ve işle ilgili güvence, bu kuşak için son derece önemlidir (Adıgüzel vd., 2014: 173; Taş ve Kaçar, 2019: 648). Yukarıdaki bilgiler 1şığında $\mathrm{X}$ kuşağının otoriteye saygılı, yöneticilere ve örgütlerine sadık, kural ve prosedürlere bağlı, kanaatkar bir kuşak olduğu söylenebilir.

\section{Y kuşağı dönemi ve özellikleri}

Yaşayan kuşaklar arasındaki farklılıkları en çok gören ve hisseden Y kuşağı, 1980-1999 yılları arasında doğan kişilerden oluşmaktadır. Teknolojik gelişmelerin etkisiyle şekillenmişlerdir. $\mathrm{Bu}$ kuşak, ebeveynlerinin gece gündüz çalıştıklarına ve yaptıkları işlere şahit olarak büyümüştür. İş hayatı ve 
dengesi üzerine kendi görüşlerini şekillendirmişlerdir (Gaidhani vd., 2019: 2806). Bilgi ve iletişim teknolojilerinin hızla ilerlediği koşullara bağlı olarak teknolojinin yoğun kullanıldığı işleri tercih etmektedirler. Y kuşağ1, teknolojik gelişmelerle birlikte özellikle internetin etkilerini yaşayan, kazanmaya ve kazanca önem veren, iş değiştirmeyi tercih edebilen bir kuşaktır. Günümüzde iş hayatında yoğun olarak bu kuşağın üyeleri bulunmaktadır (Toruntay, 2011: 74; Yüksek Bilgili, 2013: 343). Ebeveynlerinin aksine otoriteden, hiyerarşiden ve yönetilmekten hoşlanmamak gibi özellikleri vardır. Y kuşağı, iş hayatında önemli ve köklü değişimlerin olduğu, teknoloji bağımlılığının arttığı ve tüketim alışkanlıklarının değiştiği bir döneme denk gelmiştir. Deloitte firmasının yapmış olduğu bir araştırmaya göre Y Kuşağının dünya genelinde \%46'sının ve Türkiye'de \%63'ü teknoloji, medya ve haberleşme sektörlerinde çalışmak istemektedir (Taş ve Kaçar, 2019: 651). Kariyerlerinin işverenlerden ve yöneticilerden çok kendi çabalarıyla gerçekleştirebileceklerini düşünen bir kuşaktır. Bireyselciliğe karş1 güçlü eğilimleri vardır. Bireyselciliğe eğilimli olma, açık fikirlilik, değişime hızla uyum sağlayabilme, liberal olma ve pratik düşünme gibi özellikleri vardır (Park ve Park, 2018: 279). Y kuşağının X kuşağına görece daha özgürlükçü ve kişisel haklara önem verilen bir dönemde büyümesinden ötürü işlerine, işyerlerine ve yöneticilerine daha az bağlılık gösterdikleri tespit edilmiştir (Taş ve Kaçar, 2019: 655). Bu bilgiler ışığında $\mathrm{Y}$ kuşağının iş hayatında esnek çalışma şartları, yatay örgüt yapıları, danışman rolünde yönetim tarzı gibi özellikler beklediği söylenebilir.

\section{Z kuşağı dönemi ve özellikleri}

2000 yılı ve sonrasında doğan ve iş hayatına henüz yeni girmeye başlayan kuşak, Z kuşağı olarak tanımlanmaktadır. Z kuşağı, internet çağı çocukları olarak da adlandırılmaktadır. İleri teknoloji imkânları içinde iletişim ve teknoloji odaklı olan, yaşam tarzlarında sosyal medyayı yoğun kullanan ve sosyal medyadan çok etkilenen bir kuşaktır. Kendi işlerini yapmayı seven girişimci bir yapıya sahiptirler. Z kuşağı, iş beklentileri daha gerçekçi olan ve geleceğe daha olumlu bakan bir kuşaktır (Gaidhani vd., 2019: 2806). Özgürlüklerine düşkün, kısıtlamayı reddeden, esnek koşullar tercih eden bir kuşaktır. İş hayatında, bağımsız çalışmayı tercih eden ve yaptıkları işten övünerek bahseden bir kuşaktır (Kaçar, 2019: 17). Teknolojideki sürekli gelişim ile birlikte bilgiye kolay erişebilme olanaklarının artması, bu kuşağın akıllı telefonlar ve tabletler ile internet üzerinden dünyadaki bütün ülkeleri ve yaşam şekillerini takip etmelerini sağlamaktadır. Z kuşağı, teknolojiyi en iyi şekilde kullanmayı öğrenmiş ve işlerini kısa ve ciddi bir şekilde yapmaya çalışan, zevklerine düşkün ve kendilerine vakit ayırmayı seven bir kuşaktır. Sonuç odaklı bir kuşak olarak tanımlanmaları mümkündür (Kılıçlar vd., 2021: 537). Bu bilgiler 1şı̆̆ında, Z kuşağının kurallardan, prosedürlerden hiyerarşik yapılardan ve otoriteden hoşlanmayan; esnek çalışma şartlarını tercih eden bir kuşak olduğu söylenebilir.

Tarihte ilk kez bu kadar farklı kuşağın aynı iş ortamında birlikte çalıştığı görülmektedir (Aydın ve Başol, 2014: 2). Kuşaklarla ilgili yapılan bilimsel çalışmalar Y ve Z kuşaklarının X kuşağına göre farklılaştığını göstermektedir. Yapılan çalışmalarda; Y ve Z kuşaklarının sabırsız, yönetilmeyi ve otoriteyi sevmeyen ve sürekli sorgulayan kuşaklar olarak; otoriteye saygıl1, işine ve çalışma arkadaşlarına duyarlı, mücadele etmeyi bilen, kanaatkâr ve sabırlı olma gibi özellikler açısından X kuşağından farklılaştıklarını göstermektedir. Kuşakların bu farklı özellikleri işe, iş hayatına, yöneticilerine yönelik bakış açılarına ve iş performanslarına yansıyabilmektedir (Karaaslan, 2014; Saracel vd., 2016; Doğanbaş, 2017).

\section{Paternalist liderlik ve iş performansı ilişkisinde kuşak farklılıklarının etkisi}

Değişkenler arasındaki ilişkiler emik yaklaşım ve çoklu kuşak kuramı çerçevesinde açıklanabilir. İşletmelerin yönetim ve liderlik tarzları, ülkelerin sosyokültürel özellikleri tarafından etkilenmektedir (Tüz, 2004). Sosyokültürel özelliklerin toplumların yönetim, liderlik, örgütsel davranış vb. uygulamalarına etkisi, özellikle Hofstede (1980)'in ulusal kültür boyutlarına yönelik araştırmaları ile önem kazanmış, birçok kuramsal ve görgül çalışmanın konusu haline gelmiştir (Aycan, 2001: 1; Sargut ve Aktaş, 2012: 2). Bu kapsamda, konuyu sosyokültürel bağlamda ele alırken etik ve emik yaklaşımlara değinmekte fayda vardır. Kağıtçıbaşı (1990)'na göre etik yaklaşım, bir bilim dalındaki (sosyoloji gibi) ilkelerin farklı kültürel ortamlarda da geçerli olmasının; emik yaklaşım ise, her kültürde bilimsel ilkelerin farklı ve kendine özgü olmasının kabulü olarak ifade edilebilir (Erkenekli, 2012: 223). Başka bir deyişle, liderlik tarzı çerçevesinde emik yaklaşım, kişilerin hangi liderlik tarzlarını etkili olarak kabul ettikleri, kültürel özelliklere bağlı olarak farklılaşıp farklılaşmadığını belirlemekte kullanılabilir (Dorfman ve House, 2004: 53). Emik yaklaşım çerçevesinde ele alındığında paternalizm, Doğu 
toplumlarına özgü olan ve Doğu toplumlarındaki yöneticilerden beklenen kültürel bir özelliktir. Öte yandan paternalizm, Batı toplumlarında olumsuz (otokratiklik vb.) bir kültürel özellik olarak algılanmaktadır (Aycan, 2001: 2). Diğer bir ifadeyle, paternalizmi benimsemiş kültürlerde çalışan işgörenlerin yöneticilerine yönelik "sevgi" ve "korku" ikilemi, yöneticilerin ise "tatlı" ve "sert" davranışları Batı'lı bilim insanları tarafından açıklanması zor durumlar olarak değerlendirilmektedir (Aycan, 2001: 3). Bu durum, farklı yönetim ve liderlik tarzı beklentisi içinde olan kişilerin lidere yönelik tutumlarını, davranışlarını ve iş yapmakla ilgili çabalarını başka bir deyişle iş performanslarını etkileyebilmektedir.

Kuşaklar deneyimlerine bağlı olarak yöneticilere, yönetim tarzlarına, iş ve çalışma hayatına bakış açıları kapsamında birbirlerinden farklı özelliklere sahiptir (Hu vd., 2004: 335; Stanley, 2010: 849). Çoklu kuşak kuramı, kuşakların birbirlerinden farklı ekonomik, sosyolojik, kültürel, politik vb. olayları deneyimlemeleri nedeniyle farklı düşünce ve davranış kalıplarını, iş ve çalışma hayatına bakış açılarını, iş yapma usullerini vb. açıklayan kuramdır (Egri ve Ralston, 2004: 211). Diğer bir ifadeyle çoklu kuşak kuramı, günlük hayatta olduğu gibi iş hayatında da kuşakların birbirlerinden farklı özelliklere (özlük haklarına, yönetim ve liderlik tarzlarına, iş yapma usullerine, çalışma ortamı ve koşullarına, güdüleme araçlarına vb.) sahip olabileceği ve bu özelliklerin iş hayatına etkisi ile ilgili kuramdır. Çoklu kuşak kuramı, alanyazına Alman sosyolog Mannheim (1928) tarafından yazılan ve 1952 yılında İngilizceye çevrilerek "On the Problem of Generations" adıyla yayınlanan makale kapsamında kazandırılmıştır (Taylor, 2008: 4). Ancak kuram1, Inglehart (1977) ve Strauss ve Howe (1991) bilinir hale getirmiş ve kuram alanyazında sıklıkla kullanılmaya başlanmıştır (Gürbüz, 2015: 41; Kuran, 2019: 25).

Çoklu kuşak kuramından hareketle, aynı örgütte birlikte çalışan farklı kuşakların çeşitli ve birbirlerinden farklı özelliklere sahip olduğu göz önüne alındığında paternalist liderlik ve iş performansı ilişkisini olumlu etkileyebileceği (emik yaklaşım çerçevesinde) ancak X, Y ve Z kuşakları açısından (farklılaşan özellikleri çerçevesinde) istatistiksel olarak anlamlı farklılıklar ortaya çıkabileceği söylenebilir. Yazın incelendiğinde, Cheng ve Jen (2005: 34)'in Tayvan'da özel sektörde çalışan 417 kişi ile yaptıkları çalışmada paternalist liderliğin yardımseverlik boyutu $(\beta=0.14, p<0.01)$ ve ahlaki boyutu $(\beta=0.22, p$ $<0.001$ ); Wu vd. (2012: 641-642)'nin Çin'de 239 kişi ile yaptıkları çalışmada paternalist liderliğin yardımseverlik boyutu $(\beta=0.18, p<0.001)$ ve ahlaki boyutu $(\beta=0.15, p<0.001)$; Chen vd. (2014: 810)'nin Tayvan'da faaliyet gösteren 27 farklı şirkette 601 kişi ile yaptıkları çalışmada paternalist liderliğin yardımseverlik boyutu $(\beta=0.12, p<0.05)$ ve ahlaki boyutu $(\beta=0.11, p<0.05)$; ile iş performans arasında istatistiksel olarak anlamlı ve pozitif ilişki tespit edilmiştir. Wu vd. (2011: 108)'nin Çin'de 271 kişi ile yaptıkları çalışmada paternalist liderliğin yardımseverlik boyutu $(\beta=0.16, p<0.01)$ ile iş performans arasında istatistiksel olarak anlamlı ve pozitif ilişki tespit edilmiştir. Wang vd. (2018: 691)'nin 1151 Tayvan askeri ile yaptıkları çalışmada paternalist liderliğin yardımseverlik boyutu $(\beta=$ $0.21, p<0.01)$ ile iş performansı arasında istatistiksel olarak anlamlı ve pozitif ilişki tespit edilmiştir. Ugurluoglu vd. (2018)'in Türkiye'de 267 hastane çalışanı ile yaptıkları çalışmada paternalist liderliğin yardımseverlik boyutu $(\beta=0.15, p<0.001)$ ile iş performans arasında istatistiksel olarak anlamlı ve pozitif ilişki tespit edilmiştir. Yukarıdaki açıklamalar ışığında, paternalist liderlik ve iş performansı ilişkisini kuşaklar çerçevesinde ele almak alanyazına katkı sağlayacağı söylenebilir. Bu bilgilerden hareketle aşağıdaki ana hipotezler ve alt hipotezler geliştirilebilir:

Hipotez 1: Paternalist liderliğin, iş performansı üzerinde istatistiksel olarak anlamlı ve pozitif bir etkisi vardir.

Hipotez 1a: Paternalist liderliğin, bağlamsal performans üzerinde istatistiksel olarak anlamlı ve pozitif bir etkisi vardır.

Hipotez 1b: Paternalist liderliğin, görev performansı üzerinde istatistiksel olarak anlamlı ve pozitif bir etkisi vardır.

Hipotez 2: Paternalist liderliğin, iş performansı üzerindeki etkisinde kuşakların düzenleyici bir rolü vardir.

Hipotez 2a: Paternalist liderliğin, iş performansı üzerindeki etkisinde X ve Y kuşaklarının düzenleyici bir rolü vardır.

Hipotez 2b: Paternalist liderliğin, iş performansı üzerindeki etkisinde $X$ ve $Z$ kuşaklarının düzenleyici bir rolü vardır. 
Hipotez 2c: Paternalist liderliğin, iş performansı üzerindeki etkisinde $Y$ ve $Z$ kuşaklarının düzenleyici bir rolü vardır.

\section{Yöntem}

Yöntem bölmünde, öncelikle araştırmanın modeli şekil yardımıyla gösterilmiştir. Ardından çalışmanın evren ve örneklemine, verileri toplama araçları ve tekniklerine, tanımlayıcı istatistikler ve korelasyon analizi sonuçlarına, regresyon analizi sonuçlarına, düzenleyici etkiyi belirlemeye yönelik analizlere değinilmiştir.

\section{Araştırmanın modeli}

$\mathrm{Bu}$ çalışmanın araştırma modeli şekilde görüldüğü gibidir.

Şekil 1: Araştırma modeli

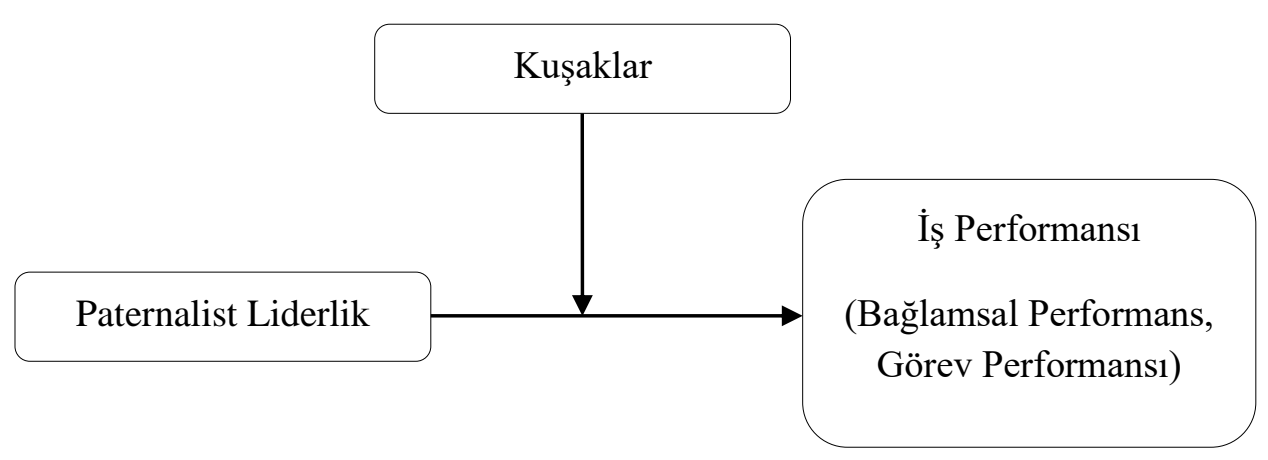

\section{Evren ve örneklem}

Çalışmanın evreni, turistik otel sayısı ve otel çalışanının yoğun olmasından ötürü Antalya, Balıkesir ve Çanakkale'de faaliyet gösteren 20 farklı turizm işletmesinden oluşmaktadır. Örneklem büyüklüğü, Baş (2001)'den yararlanılarak tespit edilmiştir (Bolat, 2017: 133). Örneklem büyüklüğü \%50 görülme sıklı̆̆1, \%5 hata payı ve \%95 güven aralığ ölçütlerine göre, 251 olarak hesaplanmıştır. Araştırmada, tanımlayıcı araştırma türü seçilmiştir. Anket uygulamada kolayda örneklem yöntemi kullanılmıştır. Çalışmanın anket uygulaması, 15 Nisan-30 Nisan 2021 tarihleri arasında internet aracılığıyla anket linkinin ilgili turizm işletmelerinin müdür ve müdür yardımcıları aracılığı ile yapılmıştır. Bu kapsamda 450 adet anket, sözkonusu işletmelerde çalışan kişilere yapılmıştır. Çalışmanın verileri, gönüllük temelli ve onam formu çerçevesinde elde edilmiştir. 311 adet anket doldurulmuştur. Anketlerin geri dönüş oranı \%69'dur. 311 anketin 5 âdetinde aynı puanlarda yoğunlaşma olduğu görülmüş ve bu anketler veri setinden çıkartılmıştır. Son olarak veri seti, 306 anketten oluşmuştur. Anket uygulaması https://forms.office.com internet sitesi aracılığıyla, onam formu ve anket gizlilik politikası çerçevesinde yürütülmüştür. Anketteki değişkenler, 1=Kesinlikle katılmıyorum-5=Kesinlikle katılıyorum şeklinde hazırlanan Likert tipinde ölçeklerle ölçülmüştür.

Örneklemde (306 kişi) kadınların oranı \%64,1 ( $\mathrm{n}=196)$, erkeklerin oranı \%35,9 $(\mathrm{n}=110) ; \% 23.9(\mathrm{n}=73)$ kişi 41-55 yaş aralığında (X kuşağı), \%47,4 (n=145) kişi 21-40 yaş aralığında (Y kuşağı), \%28,8 (n=88) kişi 20 yaş ve altındadır ( $Z$ kuşağı); Evlilerin oranı \%33,3 (n=102), bekârların oranı \% 66,7 (n=204); Mezuniyet durumuna göre oranlar, ilköğretim $\% 0,7(\mathrm{n}=2)$, ortaöğretim $\% 30,1(\mathrm{n}=92)$, ön lisans $\% 24,8$ $(\mathrm{n}=76)$, lisans $\% 35(\mathrm{n}=107)$, lisansüstü $\% 9,5(\mathrm{n}=29)$ şeklindedir.

\section{Verileri toplama araçlart ve teknikleri}

Paternalist liderlik ölçeği: Çalışmada, paternalist lider davranışlarını ölçmek için Aycan vd. (2006) tarafından oluşturulan 10 maddeli ölçekten faydalanılmıştır. Ölçek tek boyuttan oluşmaktadır. Ölçeğe, “yöneticim, çalışanlarına karşı bir aile büyüğü (baba/anne veya abi/abla) gibi davranır" örnek ifade olarak verilebilir. Ölçeğin cronbach alpha değeri 0.91'dir. Şendoğdu ve Erdirençelebi (2014:262) yaptıkları çalışmada ölçeğin cronbach alpha değerini 0.95; Cesur vd. (2015: 103) yaptıkları çalışmada ölçeğin cronbach alpha değerini 0.87; Özkacar (2020: 112) yaptığı çalışmada ölçeğin cronbach alpha değerini 0.91 olarak bulmuştur. 
İş performansı ölçeği: Çalışmada, performansı ölçmek amacıyla Goodman ve Svyantek (1999)'in iş performansını, bağlamsal performans ve görev performans1 şeklinde ölçtüğü iki başlıklı ölçek kullanılmıştır. Bağlamsal performans 16, görev performans1 9 madde ile ölçülmüştür. Bağlamsal performans ölçeğine, "işimin bir parçası olmasa da bölümümde işe yeni başlayan kişilerin işe alışmalarına yardımcı olurum" örnek ifade olarak verilebilir. Görev performansı ölçeğine, "işin amaçlarına ulaşmasını planlarım ve verilen görevi tamamlanması gereken zamanda tamamlarım" örnek ifade olarak verilebilir. Ölçeklerin cronbach alpha değerleri, bağlamsal performansın 0.82; görev performansının 0.79; genel iş performansının 0.88'dir. Ölçeği daha önce Bakker (2008), Demerouti (2014), Polatçı (2014) ve Harmancı (2018)'da kullanmışlardır (Eryılmaz, 2020: 202). Bu çalışmalarda Bakker (2008: 407), cronbach alpha değerini 0.90; Demerouti vd. (2014: 64), 0.64; Polatçı (2014: 120) cronbach alpha değerini bağlamsal performansta 0,91 , görev performansında 0,91 ve genel performansta 0,93 olarak bulmuştur. Harmancı (2018: 329), bağlamsal performansın cronbach alpha değerini 0.80, görev performansının cronbach alpha değerini ise 0.86 ; olarak tespit etmiştir.

Kuşaklar ölçeği: Kuşaklar, demografik değişkenler kısmında yer alan yaş aralığına göre belirlenmiştir. Yaş aralıkları ise yazında sıklıkla karşılaş1lan (Crampton ve Hodge, 2009: 1; Becton vd., 2014: 3) 19651979 tarih aralığında doğanlar X Kuşağı, 1980-1999 tarih aralığında doğanlar Y Kuşağı ve 2000 yılı ve sonrası doğanlar Z Kuşağı olarak sınıflandırılmıştır. Örneklemi oluşturan kişilerden (306 kişi) 73'ü (\%23.9) X kuşağına, 145’i (\%47,4) Y kuşağına, 88'i $(\% 28,8) \mathrm{Z}$ kuşağına aittir. Kuşakların bu şekilde sınıflandırılmasını Keleş (2011); Balcı ve Bozkurt (2013); Adıgüzel vd. (2014)'de kullanmıştır.

\section{Verilerin analizi}

Verilerin analizine geçmeden önce, veri setinin normal dağılıp dağılmadığını tespit etmek amacıyla "basıklık (kurtosis) ve çarpıklık (skewness) değerlerine" (Hair vd., 2010: 70; Eroğlu, 2010: 212) bakılmıştır. Basıklık ve çarpıklık değerleri bazı çalışmacılara (Mertler ve Vannatta (2005)) göre -1 ve +1 arasında olması durumunda (Çokluk vd., 2016: 16); bazı çalışmacılara (DeCarlo (1997)) göre ise -3 ve +3 arasında olması durumunda verilerin normal dağıldığı kabul edilebilir. Çalışmada paternalist liderlik ölçeğinin (basıklık 0.26, çarpıklık -0.60) ve iş performansı ölçeğinin (basıklık 1.79, çarpıklık 0.77) basıklık ve çarpıklık değerlerinin normal aralıklarda olduğu görülmüştür. Bu kapsamda veri setlerinin normal dağıldığı söylenebilir.

\section{Doğrulayıcı faktör analizi}

Faktör analizi, birbiri ile ilişkili değişkenleri daha az sayıda değişkene dönüştürerek az sayıda faktör ile analiz yapmayı sağlayan bir tekniktir. Çalışmada, daha önce belirlenmiş, çalışmalarda kullanılmış ve test edilmiş faktörleri test etmek amacıyla kullanılan doğrulayıcı faktör analizi yapılmıştır (Pallant, 2007: 179; İslamoğlu ve Alnıaçı, 2016: 416). Doğrulayıcı faktör analizi çerçevesinde, standardize çözümleme değerlerinin 1'in üzerinde ve 0.50'nin altında olmaması; t değerlerinin 1.96'ının altında olmaması; ayrıca uyum iyiliği indekslerinin de kabul edilebilir seviyede bulunması gerekir (Hair vd., 2010'den aktaran Akgündüz ve Çakıcı, 2015: 34). Bu çerçevede, çalışmada kullanılan ölçeklere doğrulayıcı faktör analizi uygulanmıştır. Çalışmanın modelinde, paternalist liderliği ölçmek için tek faktörden, iş performansını ölçmek için iki faktörden (bağlamsal performans ve görev performansı) yararlanılmıştır. Paternalist liderlik ölçeğinin uyum iyiliği değerleri, kikare $\left(X^{2}\right)$ değeri 100.30, serbestlik derecesi $(d f)$ 35, kikare serbestlik derecesi oranı $\left(X^{2} / d f\right)$ 2.86, kök ortalama kare yaklaşımı hatası (RMSEA) 0.07, karşılaştırmalı uyum indexi (CFI) 0.98, normlanmış uyum indexi (NFI) 0.97 ve düzeltilmiş uyum iyiliği indexi (AGFI) 0.90 'dir. Paternalist liderlik ölçeğinde bütün faktör yükleri 0.50 'den yüksek çıkmıştır. Ayrıca tüm $t$ değerlerinin de anlamlı olduğu $(t>-/+1.96)$ görülmüştür. İş performansı ölçeğinin uyum iyiliği değerleri, kikare $\left(X^{2}\right)$ değeri 703.39 , serbestlik derecesi $(d f) 170$, kikare serbestlik derecesi oranı $\left(X^{2} / d f\right) 4.13$, kök ortalama kare yaklaşımı hatası (RMSEA) 0.10, karşılaştırmalı uyum indexi (CFI) 0.96 , normlanmış uyum indexi (NFI) 0.94 ve düzeltilmiş uyum iyiliği indexi (AGFI) 0.77 'dir. İş performans1 ölçeğinde bağlamsal performansa ait 4., 8., 9., 10. maddeler ve görev performansına ait 8. maddenin faktör yükleri 0.50 (Hair vd., 2010: 678)'den düşük olmas1 nedeniyle bu maddeler analizlere dahil edilmemiş̧ir.

Çalışmanın uygulama (anket) kısmında kişilerin kendi kendini değerlendirmesi, paternalist liderlik davranışları ve iş performansının aynı ölçeklerle, belirli bir süre zarfında ve aynı katılımcılar aracıllı̆ı 
ile doldurulmasından ötürü ortak yöntem yanlılı̆̆ı (varyansı) (Common Method Variance) ihtimali olabilir. Ortak yöntem varyansı bulunması durumunda, ölçülen değiş̧kenler arasındaki ilişkiler, gerçekte var olmayan bir şekilde bulunabilir, bu durum ölçeğin geçerliliğini, Tip I ve Tip II sistematik ölçme hatalarının ortaya çıkmasına sebep olabilir (Bolat, 2017:150). Podsakoff vd. (2003: 889)'ne göre bu eğilimi tespit etmek amacıyla alanyazında en yaygın kullanılan tekniklerden biri olan ve bütün değişkenlerin tek faktöre yüklendiği Harman'ın tek faktör testi (Harman's single factor test) yapılmıştır. $\mathrm{Bu}$ test sonucunda, ortak yöntem yanlılığından (varyansından) bahsetmek için, ilk faktörün toplam varyansın büyük kısmını tek başına açıklaması veya analiz sonucunda tek bir faktörün bulunması gerekir. Değişkenlerine ait toplam 35 ifadeye döngüsüz faktör analizi yapılmıştır. Döngüsüz faktör analizine göre, öz değeri 1'den yüksek dört faktör bulunmuştur. Toplam varyansın birinci faktör \%36,01'ini, ikinci faktör \%12.34'ünü, üçüncü faktör \%5.13'ünü ve son olarak dördüncü faktör \%3,94'ünü açıklamaktadır. Bu bilgiler 1şığında, çalışmada ortak yöntem yanlılığı (varyansı)'nın olduğu söylenemez.

\section{Tanımlayıcı istatistikler ve korelasyon analizi sonuçları}

Paternalist liderlik, genel olarak iş performansı, bağlamsal performans ve görev performansı arasındaki iliş̧iler ile bu değişkenlerin ortalamaları, standart sapmaları ve güvenilirlik değerleri (katsayıları) Tablo 1 'de gösterilmiştir.

Tablo 1: Değişkenlerin ortalamaları, standart sapma değerleri, güvenirlik değerleri (katsayıları) ve korelasyon katsayıları

\begin{tabular}{lcccccc}
\hline Değişkenler & Ort. & SS & 1 & 2 & 3 & 4 \\
\hline 1. Paternalist Liderlik & 3.63 & 0.80 & $(0.91)$ & & & \\
2. İş̧ Performansı & 4.02 & 0.54 & $0.48^{* *}$ & $(0.88)$ & & \\
3. Bağlamsal Performansı & 4.04 & 0.56 & $0.51^{* *}$ & $0.95^{* *}$ & $(0.82)$ & \\
4. Görev Performansı & 3.98 & 0.61 & $0.37^{* *}$ & $0.90^{* *}$ & $0.73^{* *}$ & $(0.79)$ \\
\hline
\end{tabular}

Not: Değişkenlere ait Cronbach Alpha değerleri parantez içinde verilmiştir, $N=306$; ** $p<0.01$

Tablo 1'deki gösterilen korelasyon analizi sonuçlarına göre, paternalist liderlik ile iş performansı $(r=$ $0.48, p<0.01)$; bağlamsal performans $(r=0.51, p<0.01)$ ve görev performans1 $(r=0.37, p<0.01)$ arasında anlamlı ve pozitif ilişkiler tespit edilmiştir.

\section{Regresyon analizi sonuçlart}

Paternalist liderliğin iş performansı ve alt boyutlarına etkisini belirlemek amacıyla basit regresyon analizi yapılmıştır. Regresyon analizinin sonuçları Tablo 2'de gösterilmiştir.

Tablo 2: Paternalist liderliğin iş performansı ve alt boyutlarına etkisini belirlemeye yönelik basit regresyon analizi

\begin{tabular}{lccc}
\hline \multirow{2}{*}{ Değişkenler } & iş̧ Performansı & $\begin{array}{c}\text { Bağlamsal } \\
\text { Performans }\end{array}$ & $\begin{array}{c}\text { Görev } \\
\text { Performansı }\end{array}$ \\
\cline { 2 - 4 } & 6 & 6 & 6 \\
\hline Regresyon Sabiti & 2.830 & 2.751 & 2.950 \\
1. Paternalist Liderlik & $0.48^{* *}$ & $0.51^{* *}$ & $0.37^{* *}$ \\
F & 93.177 & 105.804 & 49.262 \\
$R$ & 0.484 & 0.508 & 0.373 \\
$\mathrm{R}^{2}$ & 0.235 & 0.258 & 0.139 \\
\hline
\end{tabular}

Not: Standardize edilmiş beta $(\beta)$ değerleri dikkate alınmıştır, $N=306$; ** $p<0.01$ 
Regresyon analizi sonuçlarına göre; paternalist liderliğin, iş performansı $(\beta=0.48, p<0.01)$, bağlamsal performans $(\beta=0.51, p<0.01)$ ve görev performans1 $(\beta=0.37, p<0.01)$ üzerinde istatistiksel olarak anlamlı ve pozitif etkisi olduğu tespit edilmiştir. Bu sonuçlara göre, hipotez 1, hipotez la ve hipotez $1 \mathrm{~b}$ kabul edilmiştir.

Paternalist liderliğin iş performansı üzerindeki etkisinde kuşakların düzenleyici etkisini belirlemeye yönelik analizler

Çalışmanın bu kısmında, paternalist liderliğin iş performansı üzerindeki etkisinde $\mathrm{X}, \mathrm{Y}$ ve $\mathrm{Z}$ kuşaklarının düzenleyici bir rolü olup olmadığ 1 ile ilgili analizler yapılmıştır. Düzenleyici etki analizleri sırasıyla X ve Y kuşakları, X ve Z kuşakları, $Y$ ve $Z$ kuşakları olarak analiz edilmiştir.

Tablo 3: Paternalist liderliğin iş performansı üzerindeki etkisinde $\mathrm{X}$ ve $\mathrm{Y}$ kuşaklarının düzenleyici etkisi

\begin{tabular}{lc}
\hline & iş Performansı \\
\cline { 2 - 2 } Değişkenler & 6 \\
\hline Model & \\
Regresyon Sabiti & 4.035 \\
1. Paternalist Liderlik & $0.74^{* *}$ \\
2. X-Y Kuşakları & 0.04 \\
3. Paternalist Liderlik* X-Y Kuşakları & $-0.26^{* *}$ \\
F & 29.147 \\
R & 0.538 \\
$\mathrm{R}^{2}$ & 0.290 \\
\hline
\end{tabular}

Not: Standartlaştırılmamış beta $(\beta)$ değerleri kullanılmıştır, $N=218 ; * * p<0.01 * p<0.05$

Tablo 3'te paternalist liderlik ve iş performansı ilişkisinde $\mathrm{X}$ ve $\mathrm{Y}$ kuşaklarının düzenleyici etkisini belirlemek amacıyla yapılan regresyon analizi sonuçları görülmektedir. $\mathrm{Bu}$ sonuçlara göre, $\mathrm{X}$ ve $\mathrm{Y}$ kuşaklarının $(\beta=-0.26, p<0.01)$ düzenleyici etkisi tespit edilmiştir. Düzenleyici etkiyi daha iyi anlamak için eğim analizi sonuçlarına bakılmıştır. $\mathrm{Bu}$ sonuçlara göre $\mathrm{X}$ kuşağında, paternalist liderliğin iş performansı üzerindeki etkisi ( $\beta=0.48, p<0.01)$; Y kuşağında ise $(\beta=0.22, p<0.01)$ 'dir. Paternalist liderliğin iş performansı üzerindeki etkisi, $\mathrm{X}$ ve $\mathrm{Y}$ kuşaklarına göre anlamlı düzeyde farklılaşmaktadır. $\mathrm{Bu}$ fark grafik yardımıyla da görülebilir.

Grafik 1: Paternalist liderlik ve iş performansı ilişkisinde $\mathrm{X}$ ve $\mathrm{Y}$ kuşaklarının düzenleyici etkisi

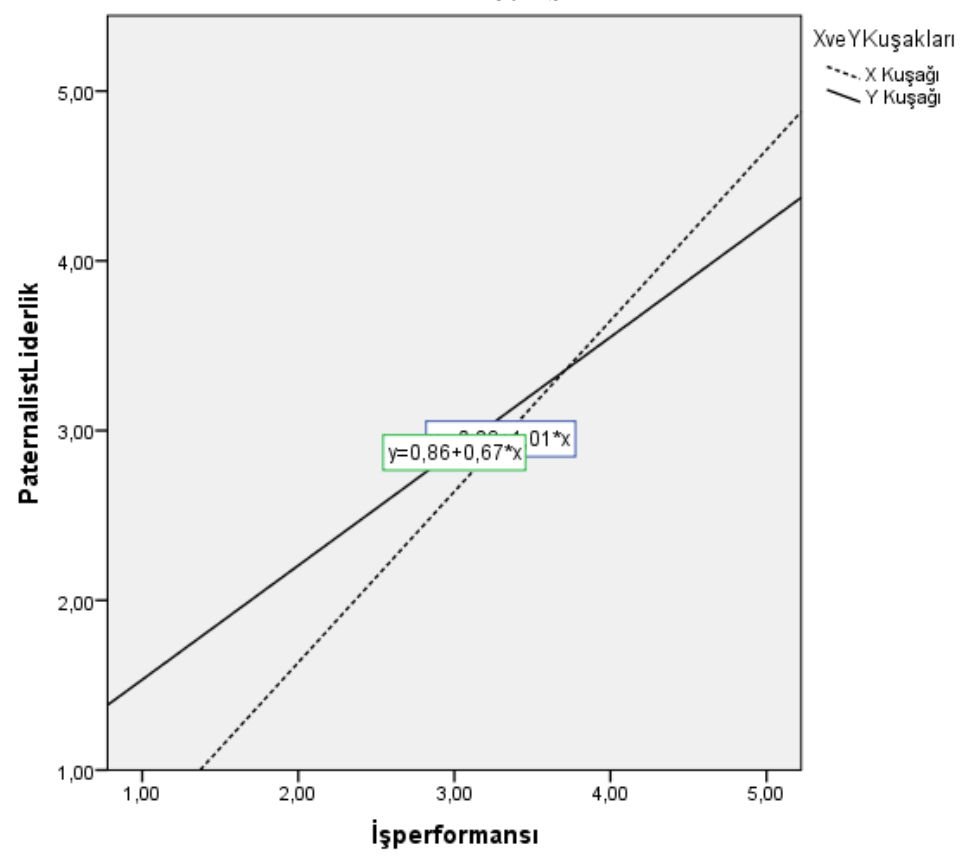


Tablo 3 ve grafik 1'e göre, hipotez $2 a$ kabul edilmiştir.

Tablo 4: Paternalist liderliğin iş performansı üzerindeki etkisinde $X$ ve $Z$ kuşaklarının düzenleyici etkisi

\begin{tabular}{lc}
\hline & \\
\cline { 2 - 2 } Değişkenler & iş Performansı \\
\hline Model & 6 \\
Regresyon Sabiti & 4.177 \\
1. Paternalist Liderlik & $0.56^{* *}$ \\
2. X-Z Kuşakları & -0.11 \\
3. Paternalist Liderlik* X-Z Kuşakları & -0.07 \\
F & 32.534 \\
$\mathrm{R}$ & 0.619 \\
$\mathrm{R}^{2}$ & 0.383 \\
\hline
\end{tabular}

Not: Standartlaştırılmamış beta $(\beta)$ değerleri kullanılmıştır, $N=161 ; * * p<0.01 * p<0.05$

Tablo 4'te de görüldüğü gibi paternalist liderlik ve iş performansı ilişkisinde $X$ ve $Z$ kuşaklarının düzenleyici etkisini belirlemek için regresyon analizi yapılmıştır. Analiz sonuçlarına göre, $X$ ve $Z$ kuşaklarının ( $\beta=-0.07, p>0.05$ ) düzenleyici etkisi tespit edilememiştir. Başka bir ifadeyle, paternalist liderliğin iş performansı üzerindeki etkisi, $X$ ve $Z$ kuşaklarına göre anlamlı düzeyde farklılaşmamaktadır. Bu sonuca göre, hipotez $2 b$ reddedilmiştir.

Tablo 5: Paternalist liderliğin iş performansı üzerindeki etkisinde $\mathrm{Y}$ ve $\mathrm{Z}$ kuşaklarının düzenleyici etkisi

\begin{tabular}{lc}
\hline & \\
\cline { 2 - 2 } Değişkenler & iş Performansı \\
\hline Model & 6 \\
Regresyon Sabiti & \\
1. Paternalist Liderlik & 4.666 \\
2. Y-Z Kuşakları & -0.01 \\
3. Paternalist Liderlik* Y-Z Kuşakları & -0.28 \\
F & 0.12 \\
R & 23.877 \\
$\mathrm{R}^{2}$ & 0.488 \\
\hline
\end{tabular}

Not: Standartlaştırılmamış beta $(\beta)$ değerleri kullanılmıştır, $N=233 ; * * p<0.01 * p<0.05$

Tablo 5'te de görüldüğü gibi, paternalist liderlik ve iş performansı ilişkisinde $\mathrm{Y}$ ve $\mathrm{Z}$ kuşaklarının düzenleyici etkisini belirlemek için regresyon analizi yapılmıştır. Bu sonuçlara göre, $Y$ ve $Z$ kuşaklarının $(\beta=0.12, p>0.05)$ düzenleyici etkisi tespit edilememiştir. Başka bir ifadeyle, paternalist liderliğin iş performansı üzerindeki etkisi, Y ve Z kuşaklarına göre anlamlı düzeyde farklılaşmamaktadır. Bu sonuca göre, hipotez $2 c$ reddedilmiştir.

Tablo 3, 4 ve 5 'te yer alan analizlere bakıldığında hipotez $2 a$ kabul edilirken hipotez $2 b$ ve hipotez $2 c$ reddedilmiştir. Bu çerçevede, hipotez 2 kısmen kabul edilmiştir.

\section{Bulgular ve tartışma}

Çalışmanın bulgularına göre, paternalist liderliğin iş performansı ve alt boyutları üzerindeki etkisini belirlemek amacıyla regresyon analizi yapılmıştır. Sonuçlara göre, paternalist liderliğin iş performansı $(\beta=0.48, p<0.01)$, bağlamsal performans $(\beta=0.51, p<0.01)$ ve görev performans1 $(\beta=0.37, p<$ $0.01)$ üzerinde istatistiksel olarak anlamlı ve pozitif etkisi tespit edilmiştir. Ayrıca paternalist liderliğin iş performansı üzerindeki etkisinde kuşakların düzenleyici etkisine bakılmıştır. Düzenleyici etki analizi bulguların göre, paternalist liderlik ve iş performansı ilişkisinde $\mathrm{X}$ ve $\mathrm{Y}$ kuşaklarının $(\beta=-0.26, p<$ 0.01) düzenleyici bulunmuştur. Başka bir ifadeyle, paternalist liderliğin iş performansı üzerindeki etkisi, $\mathrm{X}$ ve $\mathrm{Y}$ kuşaklarına göre anlamlı düzeyde farklılaşmaktadır. Öte yandan paternalist liderlik ve iş 
performansı ilişkisinde, $\mathrm{X}$ ve $\mathrm{Z}$ kuşaklarının $(\beta=-0.07, p>0.05)$ ve $\mathrm{Y}$ ve $\mathrm{Z}$ kuşaklarının $(\beta=0.12, p$ $>0.05$ ) düzenleyici etkisi tespit edilememiştir. Bu analiz sonuçlarına göre, hipotez 1, hipotez 1a, hipotez $1 \mathrm{~b}$, hipotez $2 \mathrm{a}$ kabul edilmiştir. Hipotez $2 \mathrm{~b}$ ve hipotez $2 \mathrm{c}$ reddedilmiştir. Bu durumda, hipotez 2 kısmen kabul edilmiştir.

\section{Sonuç ve öneriler}

Günümüzde örgütlerde, işgücünü daha verimli kullanmak amacıyla aynı örgütte çalışan ancak farklı deneyimleri nedeniyle iş yapma usulleri, işe ve çalışmaya bakış açıları, işe ve yöneticilere yönelik tutumları vb. konularda farklılıklara sahip kuşakları anlayabilmenin ve bu farklılıkları yönetebilmenin önemi görece arttığı söylenebilir. Bu kapsamda bu çalışmada, Doğu kültürlerine özgü olan paternalist liderlik tarzının iş performansına ve alt boyutlarına etkisi ve bu etkinin farklı kuşaklar $(\mathrm{X}, \mathrm{Y}$ ve $\mathrm{Z})$ açısından değişip değişmediği; başka bir ifadeyle kuşakların algı, tutum, davranış, işe ve çalışmaya yönelik değerlendirmeleri açısından paternalist liderliği nasıl gördükleri ve bunun iş performanslarını farklılaştırıp farklılaştırmayacağı incelenmiştir. Başka bir deyişle, bu çalışmanın aşağıda sıralanan dört temel amacı vardır. Bu amaçlar, paternalist liderlik ile iş performansı arasındaki ilişkiyi belirlemek, paternalist liderlik ile iş performansı ilişkisinde $\mathrm{X}$ ve $\mathrm{Y}$ kuşaklarının düzenleyici etkisinin olup olmadığını belirlemek, paternalist liderlik ile iş performansı ilişkisinde $X$ ve $Z$ kuşaklarının düzenleyici etkisinin olup olmadığını belirlemek, paternalist liderlik ile iş performansı ilişkisinde $\mathrm{Y}$ ve $\mathrm{Z}$ kuşaklarının düzenleyici etkisinin olup olmadığını belirlemek, şeklinde sıralanabilir.

Çalışmanın sonuçları özetlenecek olursa; paternalist liderlik ile iş performansı ve alt boyutları arasındaki ilişkiyi belirlemek için yapılan analizlere göre; paternalist liderlik ile iş performansı, bağlamsal performans ve görev performansı arasında istatistiksel olarak anlamlı ve pozitif ilişkiler tespit edilmiştir. Alanyazındaki çalışmalara bakıldığında, paternalist liderlik ile iş performansı arasındaki ilişkiye yönelik sonuçlar, Cheng ve Jen (2005), Wu vd. (2011), Wu vd. (2012), Chen vd. (2014), Wang vd. (2018:691) ve Ugurluoglu vd. (2018)'nin çalışmalarını destekler niteliktedir. Ayrıca, paternalist liderlik ile iş performansı ilişkisinde $\mathrm{X}$ ve $\mathrm{Y}$ kuşaklarının düzenleyici etkisini belirlemek için yapılan regresyon analizine göre, $\mathrm{X}$ ve Y kuşaklarının $(\beta=-0.26, p<0.01)$ düzenleyici etkisi tespit edilmiştir. Diğer bir deyişle, paternalist liderliğin iş performansı üzerindeki etkisi, $X$ ve $Y$ kuşaklarına göre anlamlı düzeyde farklılaşmaktadır. Paternalist liderlik ile iş performansı ilişkisinde $\mathrm{X}$ ve $\mathrm{Z}$ kuşaklarının düzenleyici etkisini tespit etmek için yapılan regresyon analizine göre, $\mathrm{X}$ ve $\mathrm{Z}$ kuşaklarının $(\beta=-0.07, p>0.05)$ düzenleyici etkisi tespit edilememiştir. Paternalist liderlik ile iş performansı ilişkisinde $Y$ ve $Z$ kuşaklarının düzenleyici etkisini saptamak için yapılan regresyon analizine göre, $\mathrm{Y}$ ve $\mathrm{Z}$ kuşaklarının ( $\beta$ $=0.12, p>0.05)$ düzenleyici etkisi saptanamamıştır.

Paternalist liderliğin iş performansı, bağlamsal performans ve görev performansı üzerindeki etkisi alanyazında yapılan diğer görgül çalışmalarda da (Cheng ve Jen, 2005) bulunan sonuçlara benzer şekilde anlamlı ve pozitif etki, şeklindedir. Ayrıca paternalist liderliğin, iş performansı üzerindeki etkisinde $\mathrm{X}$ ve Y kuşaklarının düzenleyici bir rolü olduğu tespit edilmiştir. Diğer bir ifadeyle, paternalist liderliğin iş performansı üzerindeki etkisi, X ve Y kuşaklarına göre anlamlı düzeyde farklılaşmaktadır. Grafik 1'den de anlaşılacağı gibi paternalist lider davranışları attıkça $X$ kuşağının iş performansı, $Y$ kuşağına göre daha fazla artmaktadır. Buradan hareketle Y kuşağının, X kuşağına görece daha esnek çalışma şartlarını tercih ettiğini söylemek mümkündür. Başka bir deyişle, Y kuşağı için esnek (zaman, mekan vb açılardan) çalışma şartları, kararlara katılım, danışman rolünde yöneticiler, esnek örgüt yapıları gibi beklentiler iş performanslarını olumlu etkileyecektir. X kuşağı zamanla iş hayatından çekilmesi ve yerini $Y$ ve $Z$ kuşaklarına bırakması, örgütlerin $Y$ ve $Z$ kuşağının çalışma hayatından beklentilerini daha fazla önemsemelerini gerektirecektir. Öte yandan, paternalist liderliğin, iş performansı üzerindeki etkisinde $X$ ve $Z$, Y ve $Z$ kuşaklarının düzenleyici bir rolü beklendiğinin aksine tespit edilememiştir. Bunun nedeni; $Z$ kuşağının örneklem büyüklüğü, ekonomik koşulların olumsuz etkisi, Kültürel anlamda kolektivist (toplulukçu) toplumun sosyal etki çerçevesindeki baskısı, çalışmanın güç mesafesinin yüksek olduğu bir toplumda yapılmış olması gibi nedenlere bağlı olabilir.

Alanyazın incelendiğinde paternalist liderlik, iş performansı ve kuşak kavramlarının önemsenen ve sıklıkla çalışılan konular arasında olduğu görülmektedir. Bu çerçevede, çalışmanın paternalist liderlik, 
ve iş performansı ilişkisinde farklı kuşakları değerlendirmesi konusunda yazına önemli bir katkı sağlayacağı söylenebilir.

Araştırma veri toplanan bölgelerle (Antalya, Balıkesir ve Çanakkale) sınırlıdır. Çalışmanın değişkenleri, uygulama sırasında kullanılan ölçeklerin güvenilirlik ve geçerlik boyutlarıyla sınırlıdır. Daha sonraki çalışmalarda, daha geniş bir örnekleme ulaşmak ve araştırmayı farklı sektörlerde de yapmak çalışmanın genellenebilirliğin için faydalı olacaktır. Çalışmada sosyal beğenilirlik, ölçülmemiştir. Sosyal beğenilirlik; kişilerin kendi algı, tutum, düşünce ve fikirlerinden çok, topluma ve sosyal çevreye göre cevaplar verme eğilimi olarak ifade edilebilir (Crowne ve Marlowe, 1960: 349-350). Sonraki çalışmalarda (özellikle iş performansı ölçülürken), sosyal beğenilirliği ölçmek amacıyla anket formuna sosyal beğenilirlik ölçekleri eklemek faydalı olacaktır. Diğer yandan, iş performansını ölçerken kendi kendini değerlendirme ve tek yöntem kullanılmıştır. İş performansını ölçerken birden farklı yöntemin kullanılması (360 derece performans değerlendirmesi, çoklu dönüt sistemi gibi) ve değerlendirme hatalarına düşülmemesini, daha sağlıklı sonuçlara ulaşmayı sağlayacaktır (İlsev, 2014: 185; Ertürk, 2018: 225).

Kuşak, aynı zaman aralığında (yaklaşık 20-25 yıl) benzer olayları deneyimleyen insan topluluğu, olarak tanımlanabilir (Ryder, 1985: 845). Kişiler, benzer deneyimler aracılığıyla kendi kuşak üyeleri ile benzer özellikler gösterirken; diğer kuşak üyelerinden örgütlerden beklentiler, iş ve çalışma hayatına verilen önem, yöneticilere ve iş arkadaşlarına yönelik tutum vb. açılardan farklılaşabilirler. Ancak bu farklılaşma ve farklılaşmanın etkilerini sadece kuşaklar açısından ele almak yanlış olur. Başka bir deyişle çalışmaya kişilik, kişilik tipleri, kişilik modelleri (beş faktör kişilik modeli gibi), örgüt kültürü, kişi iş uyumu vb. çerçeveden bakmak alanyazına katkı sağlayacaktır. Öte yandan, paternalist lider davranışları emik yaklaşım çerçevesinde ele alınmıştır. Benzer şekilde emik yaklaşımdan hareketle çalışmayı Hofstede (1984: 82-84) ve Hofstede (2011: 15)'in ulusal kültür boyutları ile birlikte (özellikle gücün toplumda nasıl dağıldığ 1 ile ilgili bir kavram olan güç mesafesi (aralığı), belirsizliğin toplum tarafından nasıl algılandığ 1 ile ilgili bir kavram olan belirsizlikten kaçınma ve diğer boyutlar olan bireyci toplumlar/çoğulcu toplumlar, eril toplumlar/dişil toplumlar) ele alınmasının ve değerlendirilmesinin yazına katkı sağlayacağı söylenebilir.

Alanyazında da ifade edildiği gibi, paternalist liderler çalışanlarından bağl1lık ve sadakat beklerken karşılığında onları koruyup kollamak, onların yerine iyilikleri için kararlar almak vb. özelliklere sahiptir. Ancak politik becerisi yüksek olan kişiler sosyal açıkgözlülük, kişilerarası ilişkilerde etkileme, ilişki kurma ve samimi görünme (Ferris vd., 2007: 297) becerileri aracıllı̆gıla liderlerini etkileyerek iç grupta yer alarak amaçlarına daha hızlı ulaşabileceklerdir (Farh ve Cheng, 2000: 92-93). Buradan hareketle paternalist liderliği, politik beceri ve lider üye etkileşimi kapsamında da ele almak faydalı olabilir.

\section{Kaynakça}

Adıgüzel, O., Batur, H. Z. ve Ekşili, N. (2014). Kuşakların değişen yüzü ve Y kuşağı ile ortaya çıkan yeni çalışma tarzı: Mobil yakalılar. Süleyman Demirel Üniversitesi Sosyal Bilimler Enstitüsü Dergisi, 19(1), 165-182.

Aguinis, H. (2013). Performance management (3. Bs.). Pearson Prentice Hall.

Aguinis, H., Joo, H. ve Gottfredson, R. K. (2012). Performance management universals: Think globally and locally. Business Horizons, 55, 385-392. https://doi.org/10.1016/j.bushor.2012.03.004

Akgündüz, Y. ve Çakıcı, A. C. (2015). Algılanan örgütsel desteğin örgütsel vatandaşlık davranışlarına etkisinde örgütsel stresin aracılık rolü: Beş y1ldızlı otel işletmelerinde bir araştırma. Journal of Alanya Faculty of Business/Alanya İsletme Fakültesi Dergisi, 7(2), 29-41.

Armstrong, M. (2006). A handbook of human resource management practice. (10. Bs.). Kogan Page, London.

Aycan, Z. (2001). Paternalizm: Yönetim ve liderlik anlayışına ilişkin üç görgül çalışma. Yönetim Araştırmaları Dergisi, 1(1), 1-26.

Aycan, Z. (2006). Paternalism. U. Kim, K. S. Yang ve K. K. Hwang (Ed.). In Indigenous and Cultural Psychology Understanding People in Context içinde (ss. 445-466) Springer.

Aydın, G. Ç. ve Başol, O. (2014). X ve Y kuşağı: Çalışmanın anlamında bir değişme var mı?. Electronic Journal of Vocational Colleges, 4(4), 1-15. 
Ayhün, S. E. (2013). Kuşaklar arasındaki farkl1lıklar ve örgütsel yansımaları. Ekonomi ve Yönetim Araştırmaları Dergisi, 2(1), 93-112.

Bakker, A. B. (2008). The work-related flow inventory: Construction and initial validation of the WOLF. Journal of Vocational Behavior, 72(3), 400-414.

Balc1 A. ve Bozkurt, S. (2013). Job expectations of generation X and Y teachers in Turkey. World Applied Sciences Journal, 21(4), 599-614.

Bayarçelik, E. B. ve Hıdır, A. H. (2020). Kuşaklara göre iş tatmini, tükenmişlik ve iş yaşam dengesi. International Journal of Management and Administration, 4(7), 54-70. https://doi.org/10.29064/ijma.665688

Becton, J. B., Walker, H. J. ve Jones-Farmer, A. (2014). Generational differences in workplace behavior. Journal of Applied Social Psychology, 44(3), 175-189.

Bolat, O. İ. (2017). Işsletme hizmet verme yatkınlı̆̆ ve tükenmişlik ilişkisi: Çalışan hizmet verme yatkınlı̆̆ ve duygusal emeğin etkisi. (1. Bs.). Detay Yayıncılık: Ankara.

Borman, W. C. ve Motowidlo, S. J. (1997). Task performance and contextual performance: The meaning for personnel selection research. Human Performance, 10, 99-109. https://doi.org/10.1207/s15327043hup1002_3

Cesur, D. K., Erkilet, A. ve Tatlan, H. H. (2015). Paternalist liderlik ve örgüt kültürü ilişkisi: Sakarya üniversitesi örneği. Akademik İncelemeler Dergisi, 14(1), 87-116.

Chen, X. P., Eberly, M. B., Chiang, T. J., Farh, J. L. ve Cheng, B. S. (2014). Affective trust in Chinese leaders: Linking paternalistic leadership to employee performance. Journal of Management, 40(3), 796-819.

Cheng, B. S. ve Jen, C. K. (2005). The contingent model of paternalistic leadership: Subordinate dependence and leader competence. In Annual Meeting of Academy of Management.

Cheng, B. S., Chou, L. F., Wu, T. Y., Huang, M. P. ve Farh, J. L. (2004). Paternalistic leadership and subordinate responses: Establishing a leadership model in Chinese organizations. Asian Journal of Social Psychology, 7(1), 89-117.

Crampton, S. M. ve Hodge, J. W. (2009). Generation Y: Unchartered territory. Journal of Business \& Economics Research, 7(4), 1-6.

Crowne, D. P. ve Marlowe, D. (1960). A new scale of social desirability independent of psychopathology. Journal of Consulting Psychology, 24(4), 349-354.

Çakmak, F. (2013). Kohort analizi ile Türkiye'deki istihdamın kuşaklara göre incelenmesi. [Yayımlanmamış Yüksek Lisans Tezi]. Atatürk Üniversitesi.

Çankır, B. ve Çelik, D.S. (2018). Çalışan performansı ve mali performans: Pozitif ses çıkarma, psikolojik iyi oluş ve çalışmaya tutkunluk ile ilişkileri ve otel işletmeleri örneği. İstanbul Gelişim Üniversitesi Sosyal Bilimler Dergisi, 5(2), 54-67. http://dx.doi.org/10.17336/igusbd.387588

Çokluk, Ö., Şekercioğlu, G. ve Büyüköztürk, Ş. (2016). Sosyal bilimler için çok değisskenli istatistik SPSS ve LISREL uygulamalart.(4. Bs.). Pagem Akademi.

Çöp, S. ve Doğanay, A. (2020). Algılanan liderlik iletişiminin iş performansı ve iş tatminine etkisi: 4 ve 5 yıldızlı otel çalışanları üzerine bir araştırma. İstanbul Gelişim Üniversitesi Sosyal Bilimler Dergisi, 7(1), 34-49. https://doi.org/10.17336/igusbd.568236

Deca, L. (2016). Beyond the stereotypes of generations X, Y and Z: Higher education for democratic innovation and enhancing citizens engagement. Higher Education for Democratic Innovation, 19.

DeCarlo, L. T. (1997). On the meaning and use of kurtosis. Psychological Methods, 2(3), 292-307.

Demerouti, E., Xanthopoulou, D., Tsaousis, I. ve Bakker, A. B. (2014). Disentangling task and contextual performance: A multitrait-multimethod approach. Journal of Personnel Psychology, 13(2), 59-69. Doi: 10.1027/1866-5888/a000104

Denisi, A. S. ve Murphy K. R. (2017). Performance appraisal and performance management: 100 years of progress. Journal of Applied Psychology, 102(3), 421-433. http://dx.doi.org/10.1037/ap10000085.supp

Doğanbaş, Z. E. (2017). Dönüşümcü liderlik ile iş tatmini arasındaki ilişkinin incelenmesi: Kuşaklar arası farklılık [Yüksek Lisans Tezi]. Çankaya Üniversitesi.

Dorfman, P. W. ve House, R. J. (2004). Cultural influences on organizational leadership: Literature review, theoretical rationale, and globe project goals. R. J. House, P. J. Hanges, M. Javidan, P. 
W. Dorfman ve V. Gupta (Ed.), Culture, leadership and organizations the GLOBE study of 62 societies içinde (ss. 51-67). Sage Publications.

Egri, C. P. ve Ralston, D. A. (2004). Generation cohorts and personal values: A comparison of China and the United States. Organization Science, 15(2), 210-220.

Erkenekli, M. (2012). Kültürel değer çalışmalarında yöntem ve sosyolojik araştırmalar için bir model önerisi. Dumlupınar Üniversitesi Sosyal Bilimler Dergisi, 33, 221-230.

Eroğlu, A. (2010). Çok değişkenli istatistik tekniklerin varsayımları. Ş. Kalaycı (Ed.), SPSS uygulamalı çok değişkenli istatistik teknikleri içinde (s. 207-230). 5. Baskı, Asil Yayın Dağıtım, Ankara.

Ertürk, M. (2018). Insan kaynakları yönetimi. (2. Bs.). Beta Basım Yayım.

Eryılmaz, İ. (2020). İş performansı. S. Polatçı (Ed.), kuramsal temelleriyle örgütsel davranış ölçekleri rehberi içinde (ss. 195-204). 1. Baskı, Nobel Akademik Yayıncılık.

Farh, J. L. ve Cheng, B. S. (2000). A cultural analysis of paternalistic leadership in chinese organizations. T. Li, A. Tsui ve E. Weldon (Ed.), Management and organizations in the Chinese context içinde (ss. 84-127). Palgrave Macmillan, London.

Feinberg, J. (1971). Legal paternalism. Canadian Journal of Philosophy, 1(1), 105-124.

Ferris, G.R. Treadway, D. C. Perrewe, P. L. Brouer, R. L. Douglas, C. ve Lux. S. (2007). Political skill in organizations, Journal of Management, 33(3), 290-320.

Gaidhani, S., Arora, L. ve Sharma, B. K. (2019). Understanding the attitude of generation Z towards workplace. International Journal of Management, Technology and Engineering, 9(1), 2804-2812.

Goodman, S. A. ve Svyantek, D. J. (1999). Person-organizational fit and contextual performance: Do shared values matter. Journal of Vocational Behavior, 55(2), 254-275.

Gürbüz, S. (2015). Kuşak farklılıkları: mit mi, gerçek mi? Işs ve Insan Dergisi, 2(1), 39-57. Doi: 10.18394/iid.80342

Hair, J., Black, W., Babin, B. ve Anderson, R. (2010). Multivariate data analysis. (7. Bs.). Pearson Education.

Harmancı, K. Y. (2018). Örgütsel yaşamda kişilik ve performans ilişkisinde pozitif duygusallığın aracı rolü. Issletme Araştırmaları Dergisi, 10(1), 321-341.

Hayek, M., Novicevic, M. M., Humphreys, J. H. ve Jones, N. (2010). Ending the denial of slavery in management history: paternalistic leadership of joseph emory davis. Journal of Management History, 16(3), 367-379. https://doi.org/10.1108/17511341011051252

Hofstede, G. (1984). Cultural dimensions in management and planning. Asia Pacific Journal of Management, 1(2), 81-99.

Hofstede, G. (2011). Dimensionalizing cultures: the Hofstede model in context. Online Readings in Psychology and Culture, 8(2), 1-26.

Hu, J., Herrick, C. ve Hodgin, K. A. (2004). Managing the multigenerational nursing team. The Health Care Manager, 23(4), 334-340.

Hung, K. H., Gu, F. F. ve Yim, C. K. B. (2007). A social institutional approach to identifying generation cohorts in China with a comparison with American consumers. Journal of International Business Studies, 38(5), 836-853.

İlsev, A. (2014). İnsan kaynakları yönetiminde performans yönetimi ve değerlendirmesi. A. Ergeneli (Ed.), insan kaynaklarl yönetimi içinde (ss. 177-205). Nobel Akademik Yayınc1lık.

İslamoğlu, A. H. ve Alnıaçı, Ü. (2015). Sosyal bilimlerde araştırma yöntemleri. (5. Bs.). Beta Basım Yayın, İstanbul.

Jawabreh, O., Masa, R., Mahmoud, R. ve Hamasha, S.A. (2020). Factors influencing the employees service performances in hospitality industry case study aqba five stars hotel. Geo Journal of Tourism and Geosites, 29(2), 649-661. https://doi.org/10.30892/gtg.29221-49

Jawahar, J. I. M. ve Carr, D. (2007). Conscientiousness and contextual performance. Journal of Managerial Psychology, 22(4), 330-349.

Kaçar, S. (2019). X, Y ve Z kuşaklarının yönetim tarzlarının karşılaştırılması örnek bir işletme araştırması. [Yüksek Lisans Tezi]. Yalova Üniversitesi.

Karaaslan, S. (2014). Kuşaklararası farklılıkları örgütler üzerinden anlamak: Bir alan araştırması [Yüksek Lisans Tezi]. Ankara Üniversitesi.

Kaya, M. ve Dinç Elmalı, E. (2021). İş karakteristiklerinin bireysel iş performansı üzerindeki etkisini belirlemeye yönelik sağlık çalışanları üzerinde bir araştırma. Journal of Life Economics, 8(1), 121-131. https://doi.org/10.15637/jlecon.8.1.12 
Keleş, H. N. (2011). Y kuşağı çalışanlarının motivasyon profillerinin belirlenmesine yönelik bir araştırma. Organizasyon ve Yönetim Bilimleri Dergisi, 3(2), 129-139.

Kılıçlar, A., Bokurt, İ., Sarıkaya, G. S. ve Şahin, A. (2021). Sosyal medyanın X ve Z kuşağı üzerindeki yemek yeme davranışına etkisi. Journal of Tourism and Gastronomy Studies, 9(1), 531-552. https://doi.org/10.21325/jotags.2021.802

Kibichii, K. E., Kiptum, K. G. ve Chege, K. (2016). Effect of performance manegement process on employee productivity: A survey of commercial banks in Turkana country. IOSR Journal of Business and Management (IOSR-JBM), 18(11), 52-64. https://doi.org/10.9790/487X1811045264

Köksal, O. (2011). Bir kültürel liderlik paradoksu: paternalizm. Mustafa Kemal Üniversitesi Sosyal Bilimler Enstitüsü Dergisi, 8(15), 101-122.

Kupperschmidt, B. R. (2000). Multigeneration employees: Strategies for effective management. The Health Care Manager, 19(1), 65-76.

Kuran, E. (2019). Z bir kuşağı anlamak. (1. Bs.). Can Sanat Yayınları, İstanbul.

Özaydın, G. ve Çelik, Y. (2020). Liderlik tarzları ve görev performansının tarım işletmelerinde yenilik stratejileri üzerine etkisi (Çumra ilçesi örneği). KSÜ Tarım ve Doğa Dergisi, 23(1), 181-193. https://doi.org/10.18016/ksutarimdoga.vi.540374

Özer, A. (2013). Çalışanların verimliliği için performans yönetimi. Kamu-İş, 13(1), 37-57.

Özer, E. (2019). Yiyecek içecek bölümü çalışanlarının iş performansı ve işten ayrılma niyetlerine ilişkin alg1 düzeylerinin belirlenmesi: Afyonkarahisar örneği. Journal of Tourism Gastronomy Studies, 7(2), 1012-1034. https://www.doi.org/10.21325/yod.13.003

Özkacar, S. (2020). Paternalist liderlik ve örgütsel sinizm ilişkisinde Hofstede’in hoşgörü/kısıtlama kültür boyutunun etkisi. [Yüksek Lisans Tezi], Balıkesir Üniversitesi.

Pallant, J. (2007). SPSS survival manual: a step by step guide to data analysis using SPSS for Windows. (3. Bs.). McGraw-Hill Education, England.

Park, S. ve Park, S. (2018). Exploring the generation gap in the workplace in South Korea. Human Resource Development International, 21(3), 276-283.

Pellegrini, E. K. ve Scandura, T. A. (2006). Leader-member exchange (LMX), paternalism, and delegation in the Turkish business culture: An empirical investigation. Journal of International Business Studies, 37(2), 264-279. Doi:10.1057/palgrave.jibs.8400185

Pellegrini, E. K. ve Scandura, T. A. (2008). Paternalistic leadership: A review and agenda for future research. Journal of Management, 34(3), 566-593. Doi: 10.1177/0149206308316063

Podsakoff, P. M., MacKenzie, S. B., Lee, J. Y. ve Podsakoff, N. P. (2003). Common method biases in behavioral research: A critical review of the literature and recommended remedies. Journal of applied psychology, 88(5), 879-903. Doi: 10.1037/0021-9010.88.5.879

Polatci, S. (2014). Psikolojik sermayenin görev ve bağlamsal performans üzerindeki etkileri: Polis teşkilatinda bir araştirma/the effects of psychological capital on task and contextual performance: A research on police organization. Ege Akademik Bakış, 14(1), 115-124.

Ryder, N. B. (1985). The cohort as a concept in the study of social change. W. M. Mason (Ed.). Cohort Analysis in Social Research içinde. Springer, New York.

Saracel, N., Taşseven, Ö. ve Kaynak, E. (2016). Türkiye'de çalışan Y kuşağında iş tatmini-motivasyon ilişkisi. Sosyal Bilimler Araştırma Dergisi, 5(1), 50-79.

Sargut, S. ve Aktaş, M. (2012). Kültür, kültürel değerler ve liderlik. A. Tabak, H. Şeşen ve T. Türköz (Ed.), Liderlikte güncel yaklaşımlar ve uygulamada kullanılabilecek ölçekler içinde (ss. 1-24). Detay Yayıncilık.

Selamat, S. ve Heryanto, H. (2019). Affecting factors in employee performance koto baru sub-district, dharmasraya district. Archives of Business Research, 7(7), 142-154.

Stanley, D. (2010). Multigenerational workforce issues and their implications for leadership in nursing. Journal of Nursing Management, 18(7), 846-852. Doi: 10.1111/j.13652834.2010.01158.x

Suber, P. (1999). Paternalism. C. B. Gray (Ed.), The philosophy of law: an encyclopedia içinde. Garland Pub. II. New York, London.

Şalap, K. O. ( 2016). Çalışma yaşamında kuşaklar: Kuşakların iş ve özel yaşam dengesine ilişkin yaklaşımları. [Yüksek Lisans Tezi]. İstanbul Üniversitesi. 
Şendoğdu, A. A. ve Erdirençelebi, M. (2014). Paternalist liderlik ile örgütsel vatandaşlık davranış1 arasındaki ilişkiye yönelik bir araştırma. Selçuk Üniversitesi İktisadi ve İdari Bilimler Fakültesi Sosyal ve Ekonomik Araştırmalar Dergisi, 14(27), 253-274.

Taş, Y. H. ve Kaçar, S. (2019). X, Y ve Z kuşağı çalışanlarının yönetim tarzları ve bir işletme örneği. Uluslararası Toplum Araştırmaları Dergisi-International Journal Of Society Researches, 18(11), 643-675. https://doi.org/10.26466/opus.554751

Taylor, J. C. (2008). Whither march the cohorts: the validity of generation theory as a determinant of the sociocultural values of Canadian forces personnel. Toronto: Canadian Forces College National Security Studies Program.

Tolay, E. (2020). Paternalist liderlik beklentisi: Y kuşağı işletme öğrencileri üzerine bir araştırma. İzmir Íktisat Dergisi, 35(1), 123-139. https://doi.org/10.24988/ije.202035110

Toruntay, H. (2011). Takım rolleri çalışması: X ve Y kuşağı üzerinde karşılaş̧tırmalı bir araştırma. [Yayımlanmamış Yüksek Lisans Tezi]. İstanbul Üniversitesi.

Tüz, M. (2004). İşletmelerde yönetim modelleri Avrupa, Amerika, Japonya, Türkiye uygulamalı. (1. Bs.). Aktüel Yayınları, Bursa.

Ugurluoglu, O., Aldogan, E. U., Turgut, M. ve Ozatkan, Y. (2018). The effect of paternalistic leadership on job performance and intention to leave the job. Journal of Health Management, 20(1), 46-55. Doi: $10.1177 / 0972063417747700$

Uysal, Ş. (2015). Performans yönetim sisteminin tanımı, tarihçesi, amaç ve temel unsurlarına genel bir bakış. Electronic Journal of Vocational Colleges, 5(2), 32-39.

Ünlü, O. ve Yürür, S. (2011). Duygusal emek, duygusal tükenme ve görev/bağlamsal performans ilişkisi: Yalova'da hizmet sektörü çalışanları ile bir araştırma. Erciyes Üniversitesi İktisadi ve İdari Bilimler Fakültesi Dergisi, 37, 183-207.

Wang, A. C., Tsai, C. Y., Dionne, S. D., Yammarino, F. J., Spain, S. M., Ling, H. C., ve Cheng, B. S. (2018). Benevolence-dominant, authoritarianism-dominant, and classical paternalistic leadership: testing their relationships with subordinate performance. The Leadership Quarterly, 29(6), 686697. https://doi.org/10.1016/j.leaqua.2018.06.002

Westwood, R. (1997). Harmony and patriarchy: The cultural basis for "paternalistic headship" among the overseas Chinese. Organization Studies, 18(3), 445-480. https://doi.org/10.1177/017084069701800305

Wu, M., Huang, X. ve Chan, S. C. (2012). The influencing mechanisms of paternalistic leadership in mainland China. Asia Pacific Business Review, 18(4), 631-648. https://doi.org/10.1080/13602381.2012.690940

Wu, M., Huang, X., Li, C. ve Liu, W. (2011). Perceived interactional justice and trust-in-supervisor as mediators for paternalistic leadership. Management and Organization Review, 8(1), 97-121. Doi:10.1111/j.1740-8784.2011.00283.x

www.tdk.gov.tr, Erişim Tarihi: 02.04.2021.

Yüksek Bilgili, Z. (2013). Türk tipi y kuşağı. Elektronik Sosyal Bilimler Dergisi, 12(45), 342-353.

\section{Etik kurul onayı}

Çalışmanın etik kurul onayı, Balıkesir Üniversitesi Sosyal ve Beşeri Bilimler etik kurulunun 08.04.2021 ve 2021/02 sayılı toplantısında alınmıştır. Etik kurul onayına ilişkin evrak tarih ve sayısı, 14.04.2021E.27584'dür. Belge Doğrulama Kodu: BE6P5NZ5V.

\section{Araştırmacıların katkı oranı beyanı}

Yazarlar çalışmaya eşit oranda katkı sağlamıştır.

Çıkar çatışması beyanı

Bu çalışmada herhangi bir potansiyel çıkar çatışması bulunmamaktadır. 